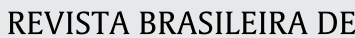

\section{A revision of the subgenera Euhyboma Kolbe, 1893, Parahyboma Paulian, 1938, and Rubrohyboma Paulian, 1939 of Deltochilum Eschscholtz, 1822 (Coleoptera: Scarabaeidae: Scarabaeinae)}

\author{
Everton E. Nazaré-Silva ${ }^{1, *} \mathbb{C}^{0}$, Fernando A. B. Silva ${ }^{1,2}$ \\ ${ }^{1}$ Universidade Federal do Pará, Programa de Pós-graduação em Zoologia, Belém, PA, Brasil. \\ ${ }^{2}$ Universidade Federal Rural de Pernambuco, Unidade Acadêmica de Serra Talhada (UAST), Serra Talhada, PE, Brasil. \\ urn:lsid:zoobank.org:pub:1CC9E1C1-CD5F-4673-8616-C80FDD645723
}

\section{A R T I C L E I N F O}

\section{Article history:}

Received 30 September 2020

Accepted 28 June 2021

Available online 30 July 2021

Associate Editor: Lúcia Almeida

\section{Keywords:}

Atlantic rainforest

Deltochilini

Dung beetles

Taxonomy

Identification key

\begin{abstract}
A B S T R A C T
This paper provides a revision of the three smallest subgenera of Deltochilum, all endemic to the Atlantic Forest of South America. Deltochilum (Euhyboma) and D. (Rubrohyboma) are monospecific taxa, composed of $D$. brasiliense (Castelnau, 1840) and D. rubripenne (Gory, 1831), respectively, whereas D. (Parahyboma) is composed of two allopatric species, D. furcatum (Castelnau, 1840) and D. granulosum Paulian, 1933. Lectotypes for D. brasiliense and $D$. rubripenne are designated. Each species is analyzed as follows: a detailed literature review, a diagnosis, description, illustrations of key morphological characters, list of material examined, and geographic distribution. An improved identification key to the subgenera of Deltochilum is presented.
\end{abstract}

\section{Introduction}

Deltochilum Eschscholtz, 1822 is one of the most diverse dung beetle genera, including 107 valid species and 4 subspecies (Schoolmeesters, 2020). It is distributed from the south of the United States of America to the north of Argentina (Vaz-de-Mello et al., 2011; Schoolmeesters, 2020), and its greatest diversity is associated with tropical forests (Vazde-Mello, 1999). Currently, the genus is divided into eight subgenera: Aganhyboma Kolbe, 1893, Calhyboma Kolbe, 1893, Deltochilum s. str., Deltohyboma Lane, 1946, Euhyboma Kolbe, 1893, Hybomidium Shipp, 1897, Parahyboma Paulian, 1938 and Rubrohyboma Paulian, 1939 (Shipp, 1897; Paulian, 1938, 1939; Pereira and Martínez, 1956; Vulcano and Pereira, 1964; Génier, 2012).

The subgenus Deltochilum (Euhyboma) was described by Kolbe (1893) for Deltochilum brasiliense (Castelnau, 1840), type species of the subgenus by monotypy (Lane, 1946). This species has been previously recorded in Colombia, Brazil, and Argentina (Kolbe, 1893; Paulian,

\footnotetext{
* Corresponding author.

E-mail: evertonensilva@gmail.com (E.E. Nazaré-Silva).
}

1938; Vulcano and Pereira, 1964), being historically diagnosed by the following characters: large body size, elytra with short lateral carina and epipleural carina absent (Kolbe, 1893; Vaz-de-Mello et al., 2011).

Deltochilum (Parahyboma) was described by Paulian (1938) for the species Deltochilum furcatum (Castelnau, 1840) and D. granulosum Paulian, 1933. The author originally designated $D$. furcatum as the type species. The subgenus has only been recorded from Brazil (Paulian, 1938; Vulcano and Pereira, 1964). The following diagnostic characters were provided by Paulian (1938) for the subgenus: small body size, convex, with short legs; clypeus quadridentate; and metaventrite with a single posterior pit, without tubercles.

Deltochilum (Rubrohyboma) was described by Paulian (1939) for Deltochilum rubripenne (Gory, 1831). Its specimens have been recorded from Argentina, Brazil, and Paraguay (Paulian, 1939; Pessôa and Lane, 1941; Martínez, 1959; Vulcano and Pereira, 1964). The characters defined by Paulian (1939) for the diagnosis of the subgenus are the small and rounded body, clypeus bidentate, carina of ninth elytral interstria and protarsi absent. 
An examination of collections revealed new distribution data for the species of these subgenera. Furthermore, the available species descriptions are not sufficient for species identification purposes, and they do not include modern taxonomic techniques, such as the use of high-quality images with illustration of the aedeagus and its endophallites. This paper aims to present a taxonomic revision of the subgenera Euhyboma, Parahyboma, and Rubrohyboma, providing information on species identities, identification and geographical distributions. In this study, endophallites of the male genitalia of D. (Euhyboma) brasiliense (Castelnau, 1840), D. (Parahyboma) furcatum (Castelnau, 1840), D. (Parahyboma) granulosum Paulian, 1933 and D. (Rubrohyboma) rubripenne (Gory, 1831) are also described and illustrated for the first time.

\section{Material and methods}

A total of 834 adult specimens of Deltochilum were examined. The examined material was kindly provided as follows: specimens from CEMT and MZUFPA were examined by us; the type material of all species names was examined from photos provided by Dr. Fernando Z. Vaz-de-Mello; MSc. Mario Cupello kindly provided data from CEIOC, DZUP, and MNRJ.

CEIOC - Coleção Entomológica do Instituto Oswaldo Cruz, Rio de Janeiro, Brazil (Jane Costa)

CEMT - Seção de Entomologia da Coleção Zoológica, Departamento de Biologia e Zoologia, Universidade Federal de Mato Grosso, Cuiabá, Brazil (Fernando Z. Vaz-de-Mello)

DZUP - Coleção Entomológica Padre Jesus Santiago Moure, Departamento de Zoologia, Universidade Federal do Paraná, Curitiba, Brazil (Lucia Massuti de Almeida)

IRSN - Institut royal des Sciences naturelles de Belgique, Brussels, Belgium (Alain Drumont)

MNRJ - Museu Nacional, Universidade Federal do Rio de Janeiro, Rio de Janeiro, Brazil (Miguel A. Monné and Marcela L. Monné)

MZUFPA - Coleção de Scarabaeinae do Setor de Zoologia, Instituto de Ciências Biológicas, Universidade Federal do Pará, Belém, Brazil (Fernando A.B. Silva).

MNHN - Muséum national d'Histoire naturelle, Paris, France (Olivier Montreuil, Antoine Mantilleri; only types studied)

OUMNH - Oxford University Museum of Natural History, Oxford, United Kingdom (Darren Mann; only types studied).

Examination of the tegmen and its structural components (parameres and phallobase) as well as of the endophallus and its endophallites was undertaken to clarify differences among species. The terminology used to describe these structures followed Tarasov and Solodovnikov (2011) and Tarasov and Génier (2015), with modifications by Silva et al. (2015) and Génier (2019).

The dissection of the male genitalia followed the preparation technique suggested by Zunino (1978). The endophallus was removed from the tegmen through the basal foramen of the phallobase, and its endophallites were illustrated. The Axial and Subaxial (A+SA) and the Frontolateral Peripheral endophallites (FLP) were illustrated in dorsal view. The Superior Right Peripheral (SRP) endophallite was illustrated in ventral view. The lamella copulatrix (LC) is composed of two parts in all species addressed here, named the left lobe and the right lobe by Silva et al. (2015). The left lobe was illustrated in ventral view, and the right lobe in dorsal view.

Photographs were taken with a Leica stereomicroscope M205A, using image stacking software (Leica Application Suite, version 4.2). The images were edited using Adobe Photoshop CC 2019. Species distribution were represented through maps using the software Quantum gis (Qgis, version 3.4). Geographic distribution for each species was given according the biogeographic dominions and provinces as defined by Morrone (2014).

Type specimens labels were transcribed ipsis litteris in quotation marks ("”). Labels were separated with a double slash (//) and line breaks in the same label with a single slash $(/)$. Italic text indicates labels handwritten.

\section{Results}

Key to the subgenera of Deltochilum and species of Parahyboma (modified from Vaz-de-Mello et al., 2011).

1. Head (between clypeogenal sutures) prolonged anteriorly, similar to a "muzzle" (Fig. 1A). Mexico to Argentina, except Chile....

D. (Aganhyboma) Kolbe, 1893

- Head not prolonged anteriorly (Fig. 1B)

2 (1). Ninth elytral interstria lacking carina basally, or carina inconspicuous (Fig. 1F). . 3 - Ninth elytral interstria distinctly carinate basally (Figs 1D-E)...

3 (2). Protarsi absent. Elytral interstriae 1-7 with a longitudinal row of tubercles (Fig. 5A). Atlantic Forest from Southeastern of Brazil to northeastern Argentina (Fig. 8C) ..........

. D. (Rubrohyboma) rubripenne (Gory, 1831) (Figs 5A-B)

- Protarsi small, but present. Elytral interstriae 1-7 lacking tubercles, or with tubercles not arranged longitudinally. Mexico to Argentina.... D. (Calhyboma) Kolbe, 1893

4 (2). Carina of ninth interstria present at least on the basal 3/4 of interstria. USA to Brazil.............. . D. (Deltochilum) s. str. Eschscholtz, 1822

- Carina of ninth interstria extending at most to half the length of interstria. . .5

5 (4). Pseudoepipleural carina lacking at basal part of elytra (Fig. 1D). Atlantic Forest from northeastern Brazil to northeastern Paraguay and Argentina (Fig. 8A)........D. (Euhyboma) brasiliense (Castelnau, 1840) (Figs 2A-B)

- Pseudoepipleural carina distinct basally (Fig. 1E)...........................6

6 (5). Clypeus bidentate. Mexico to Argentina.... D. (Deltohyboma) Lane, 1946

- Clypeus quadridentate 7

7 (6). Metaventrite bituberculate posteriorly. USA to Argentina. D. (Hybomidium) Shipp, 1987

- Metaventrite lacking posterior tubercles. D. (Parahyboma) Paulian, 1938.

8 (7). Dorsal surface of the body black and opaque(Fig. 3A). Microtubercles of elytral interstriae elliptical and spaced approximately by one diameter (Fig. 1G). Parameres with apical projection shorter and pointed in lateral and ventral view (Fig. 6B). Mid-apical region of the SRP cable strongly curved outward (Fig. 7B). Left lobe of the lamella copulatrix "water drop"shaped; right lobe subtriangular, shorter than left lobe (Fig. 7B). Atlantic Forest from southeastern Brazil to Argentina and Paraguay (Fig. 8B)..

D. (Parahyboma) furcatum (Castelnau, 1840) (Figs 3A-B)

- Dorsal surface of the body light brown and shiny (Fig. 4A). Microtubercles of elytral interstriae in general, rounded, denser with microsculpture almost confluent (Fig. 1H). Parameres with apical projection slightly rounded in lateral and ventral views (Fig. 6C). Mid-apical region of the 

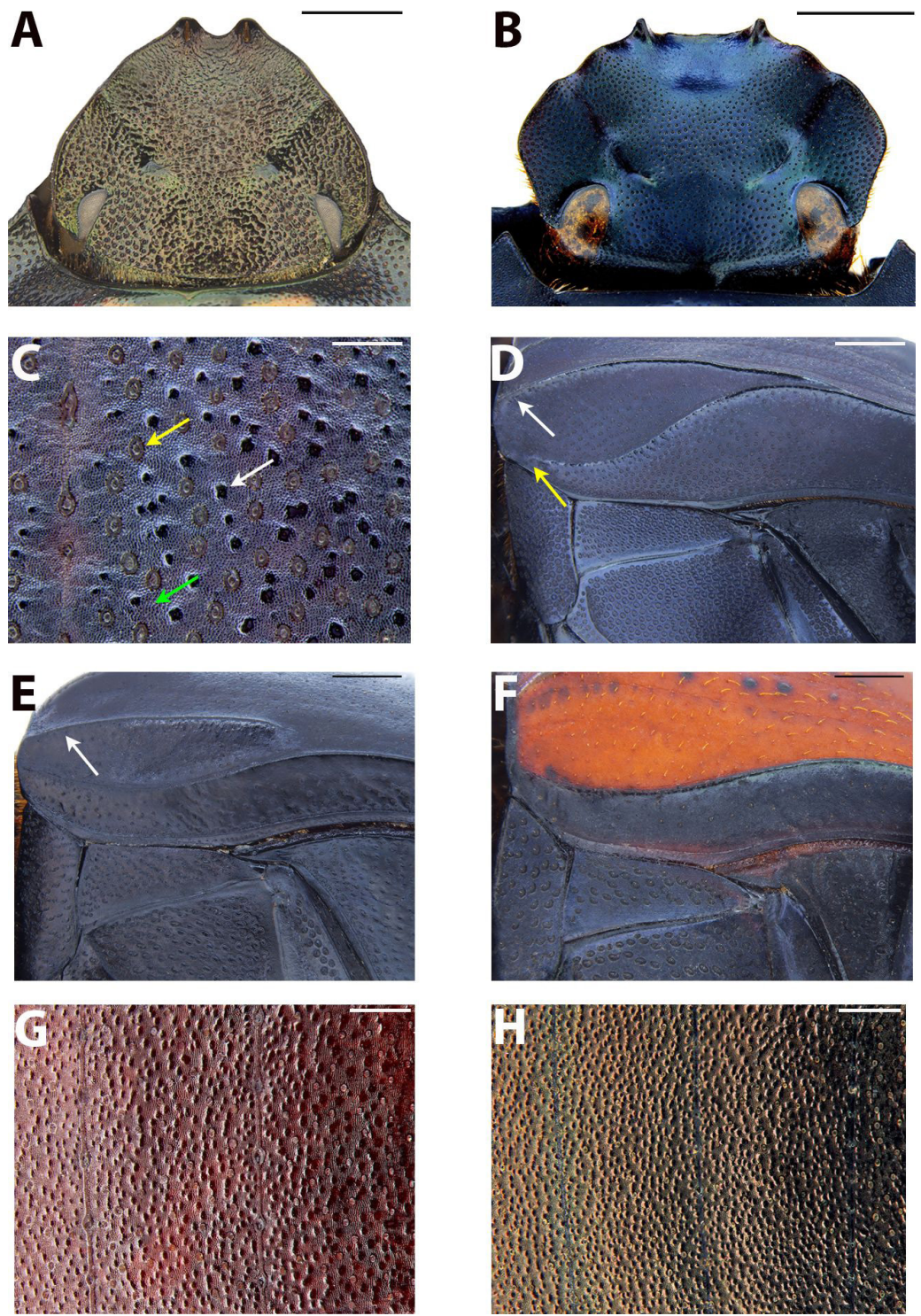

Figure 1 Details of the external morphology in species of Deltochilum Eschscholtz, 1822.(A) Head in Deltochilum (Aganhyboma) trisignatum Harold, 1881. (B) Head in D. (Euhyboma) brasiliense (Castelnau, 1840). (C) Surface of third elytral interstria in D. brasiliense (arrows indicate details of microsculpture. Yellow: foveiform punctures; white: microtubercles; green: granulation). (D-F) Lateral view of elytra in species of Deltochilum (white arrows indicate carina of ninth elytral interstria; yellow arrow indicate pseudoepipleural carina lacking at basal part of elytra). (D) D. brasiliense. (E) D. (Parahyboma) furcatum (Castelnau, 1840). (F) D. (Rubrohyboma) rubripenne(Gory, 1831). (G-H) Details of elytral surface. (G) D. (Parahyboma) furcatum. (H) D. (Parahyboma) granulosum. Figures scale: A, B, G, H (1 mm); C (0,5 mm); D-F (2 mm).

SRP cable curved in approximately 90 degrees (Fig. 7C). Left lobe of the lamella copulatrix comma shaped (Fig. 7C); right lobe subrectangular, curved, with approximately the same length as the left lobe (Fig. 7C). Atlantic Forest in Bahia and Espírito Santo (Brazil) (Fig. 8B).

D. (Parahyboma) granulosum Paulian, 1933 (Figs 4A-B)

\section{Deltochilum (Euhyboma) Kolbe, 1893}

Deltochilum (Euhyboma) Kolbe, 1893: 191 (original description); Paulian, 1938: 243, 257, 258 (identification key and redescription); Blackwelder, 1944: 202 (checklist); Lane, 1946: 174(taxonomic remarks); Pereira and Martínez, 1956: 121, 122 (catalogue and identification key); Vulcano and Pereira, 1964: 646 (catalogue); Halffter and Matthews, 1966: 261 (checklist and distribution); Halffter and Edmonds, 1982: 139 (checklist and distribution); Vaz-de-Mello, 2000: 192 (checklist); Medina et al., 2003: 65 (list of species and distribution); Krajcik, 2006: 47 (checklist); González-Alvarado et al., 2009: 254 (identification key); Vaz-de-Mello et al.,
2011: 5, 11, 18, 26, 33, 41, 44, 56 (checklist and identification key); Krajcik, 2012: 88 (checklist); Vaz-de-Mello, 2020 (checklist).

Euhyboma Shipp, 1897: 195 (taxonomic remarks)

Deltochilum (Euhyboma) brasiliense (Castelnau, 1840)

(Figs 1B-D, 2A-H, 6A, 7A, 8A)

urn:Isid:zoobank.org:act:3C695DDF-888C-4DC1-8FBB-5CF8CC17A314 Hyboma brasiliense Castelnau, 1840: 73 (original description); Pereira and Martínez, 1956: 122 (cited as type species)

Deltochilum brasiliense Burmeister, 1848: 135 (distribution and redescription); Redtenbacher, 1868: 54 (checklist and distribution); Harold, 1869: 995 (catalogue and distribution); Harold, 1875: 60 (taxonomic remarks); Gillet, 1911: 35 (catalogue); Pessôa and Lane, 1941: 428, 432 (catalogue, description, distribution, identification key, and taxonomic remarks); Blackwelder, 1944: 202 (checklist and distribution); Vulcano et al., 1980: 116 (checklist); Medina et al., 2001: 

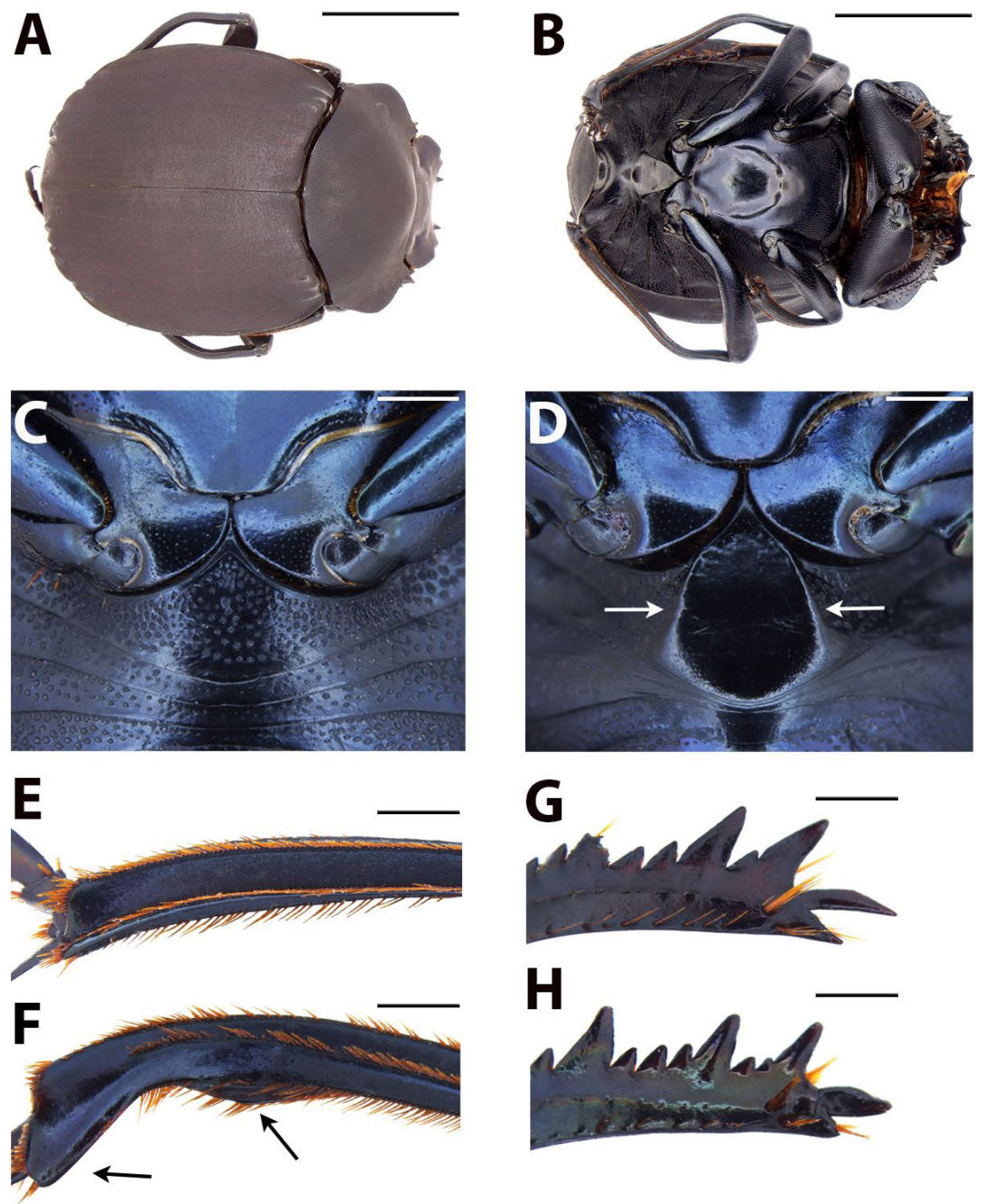

Figure 2 Deltochilum (Euhyboma) brasiliense(Castelnau, 1840). (A) Dorsal view. (B) Ventral view. (C) Details of abdominal ventrites of females. (D) Details of abdominal ventrites of males (diagonal carina pointed). (E) Metatibia of females (F) Metatibia of males (lobes pointed). (G) Protibia of females, ventral view. (H) Protibia of males, ventral view. Figures scale: A-B $(5 \mathrm{~mm}) ; \mathrm{C}-\mathrm{H}(1 \mathrm{~mm})$.
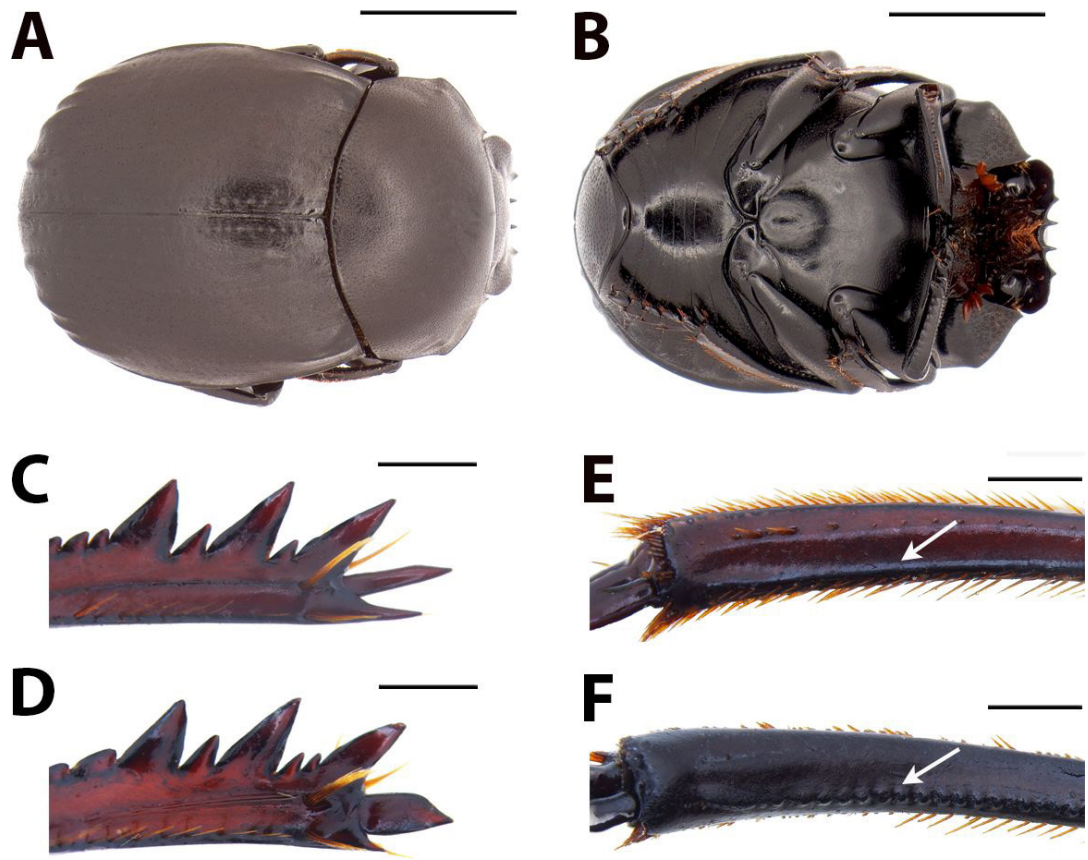

Figure 3 Deltochilum (Parahyboma) furcatum (Castelnau, 1840). (A) Dorsal view. (B) Ventral view. (C) Protibia of females, ventral view. (D) Protibia of males, ventral view. (E) Metatibia of females (arrow indicates longitudinal carina). (F) Metatibia of males (arrow indicates longitudinal row of tubercles). Figures scale: A-B (5 mm); C-F (1 mm). 

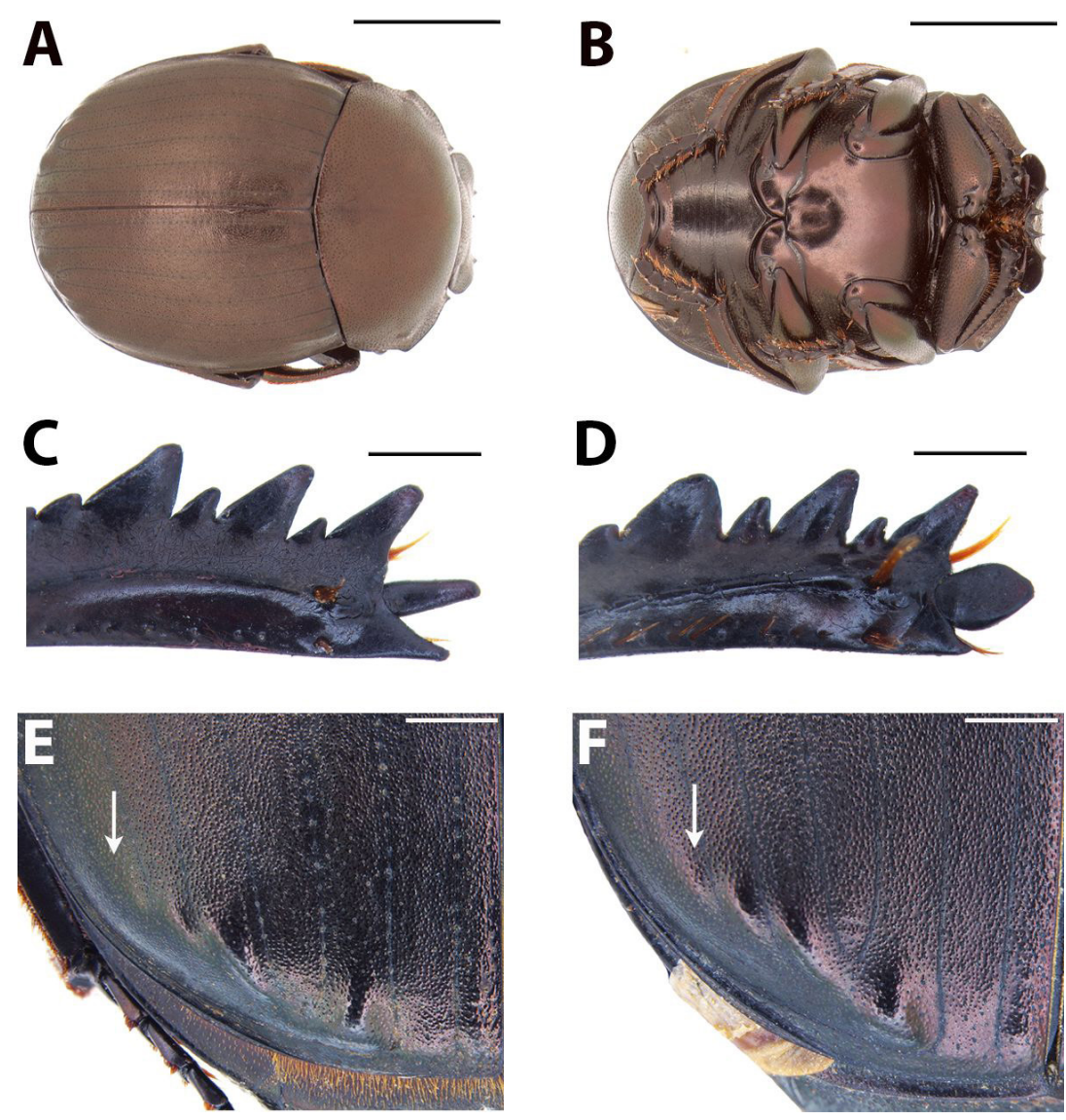

Figure 4 Deltochilum (Parahyboma) granulosum Paulian, 1933. (A) Dorsal view. (B) Ventral view. (C) Protibia of females, ventral view. (D) Protibia of males, ventral view. (E) Elytral apex of females (arrow indicates seventh elytral interstria lacking carina). (F) Elytral apex of males (carina of seventh elytral interstria pointed). Figures scale: A-B (5 mm); C-F (1 mm).
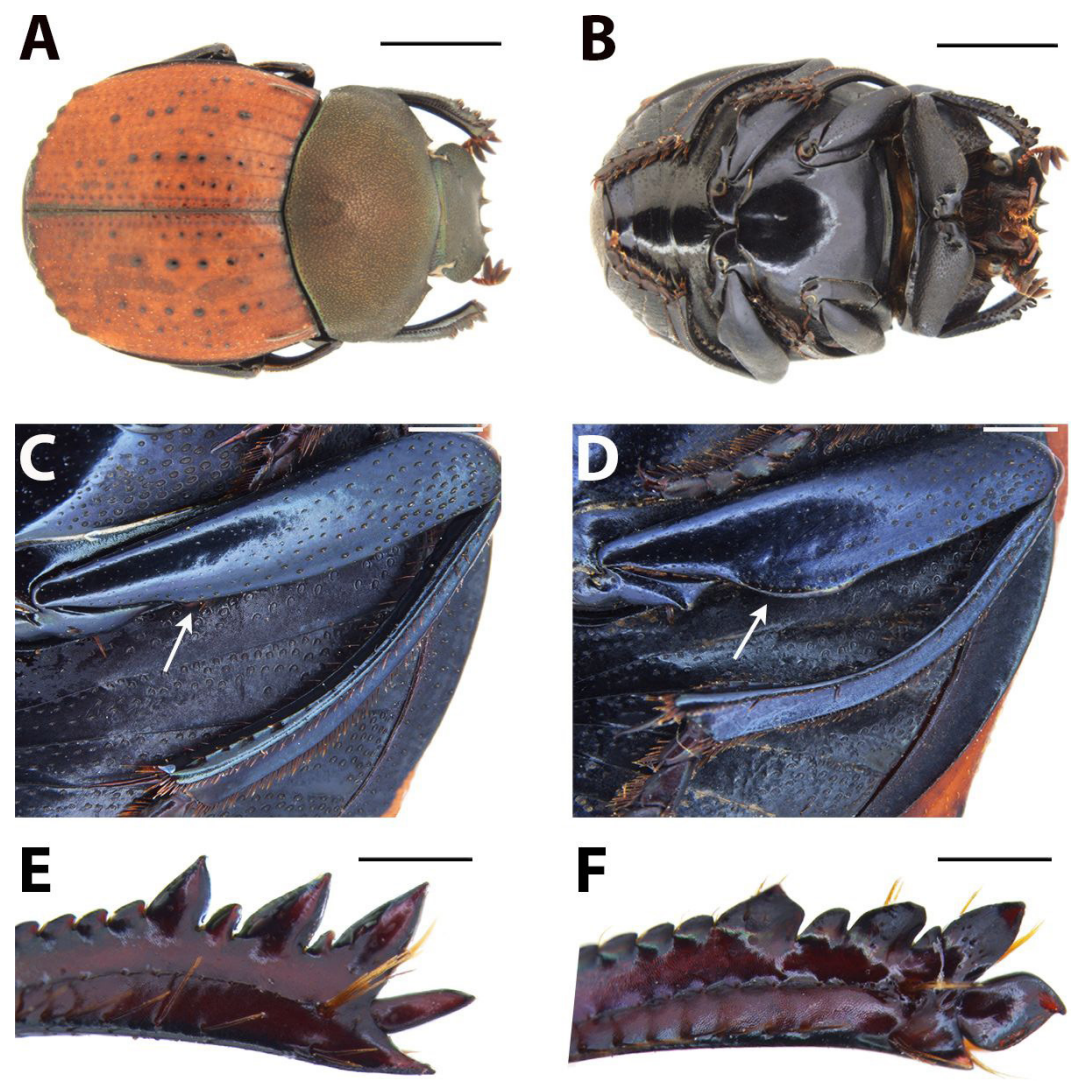

Figure 5 Deltochilum (Rubrohyboma) rubripenne (Gory, 1831). (A) Dorsal view. (B) Ventral view. (C) Metafemur of females (arrow indicates posterior edge not expanded). (D) Metafemur of males (arrow indicates posterior edge expanded). (E) Protibia of females, ventral view. (F) Protibia of males, ventral view. Figures scale: A-B (5 mm); C-F (1 mm). 

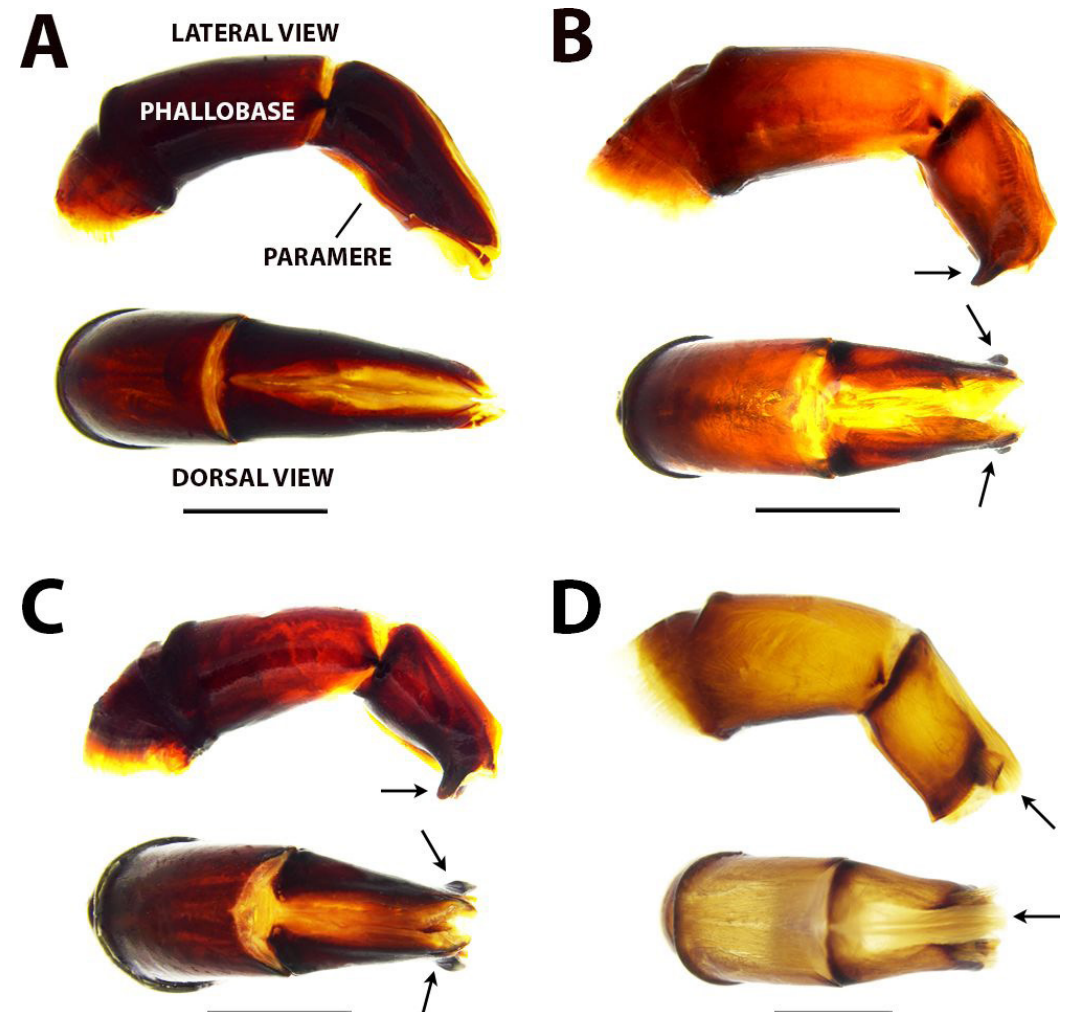

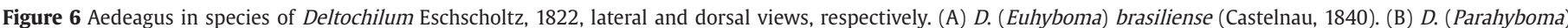

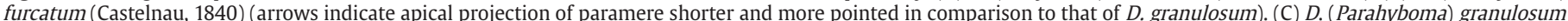

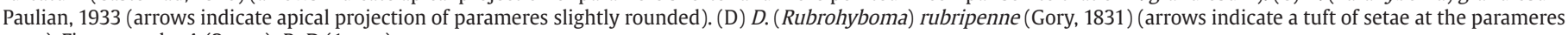
apex). Figures scale: A (2 mm); B-D (1 mm).
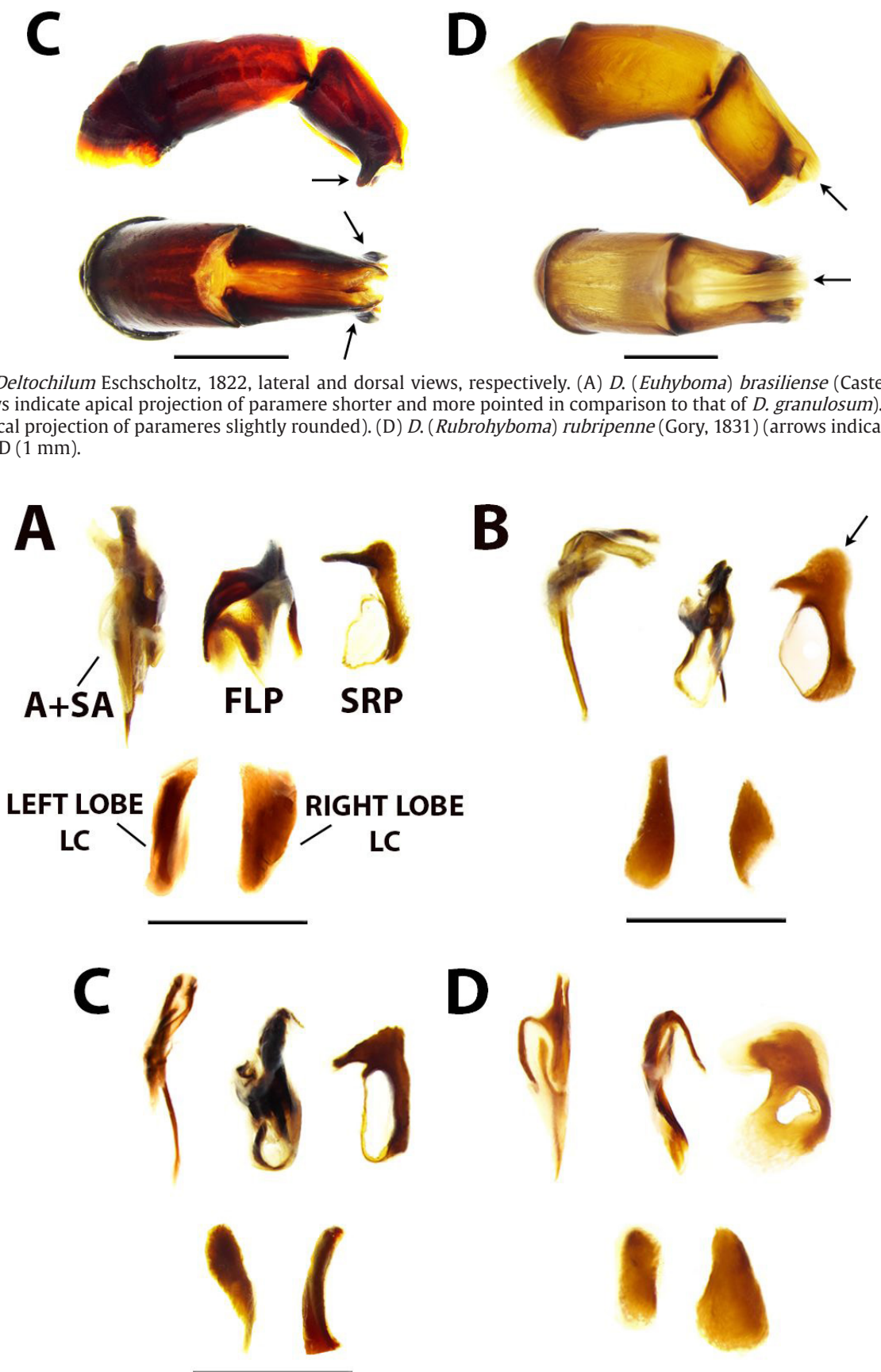

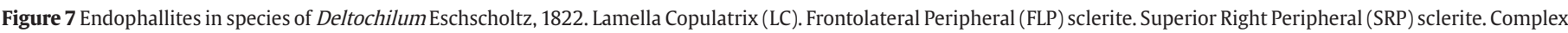

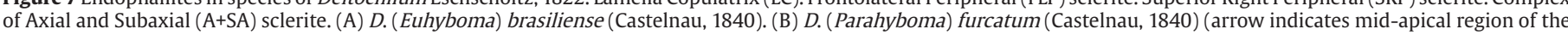
SRP cable strongly curved outward). (C) D. (Parahyboma) granulosum Paulian, 1933. (D) D. (Rubrohyboma) rubripenne(Gory, 1831). Figures scale: A-D (0,5 mm). 

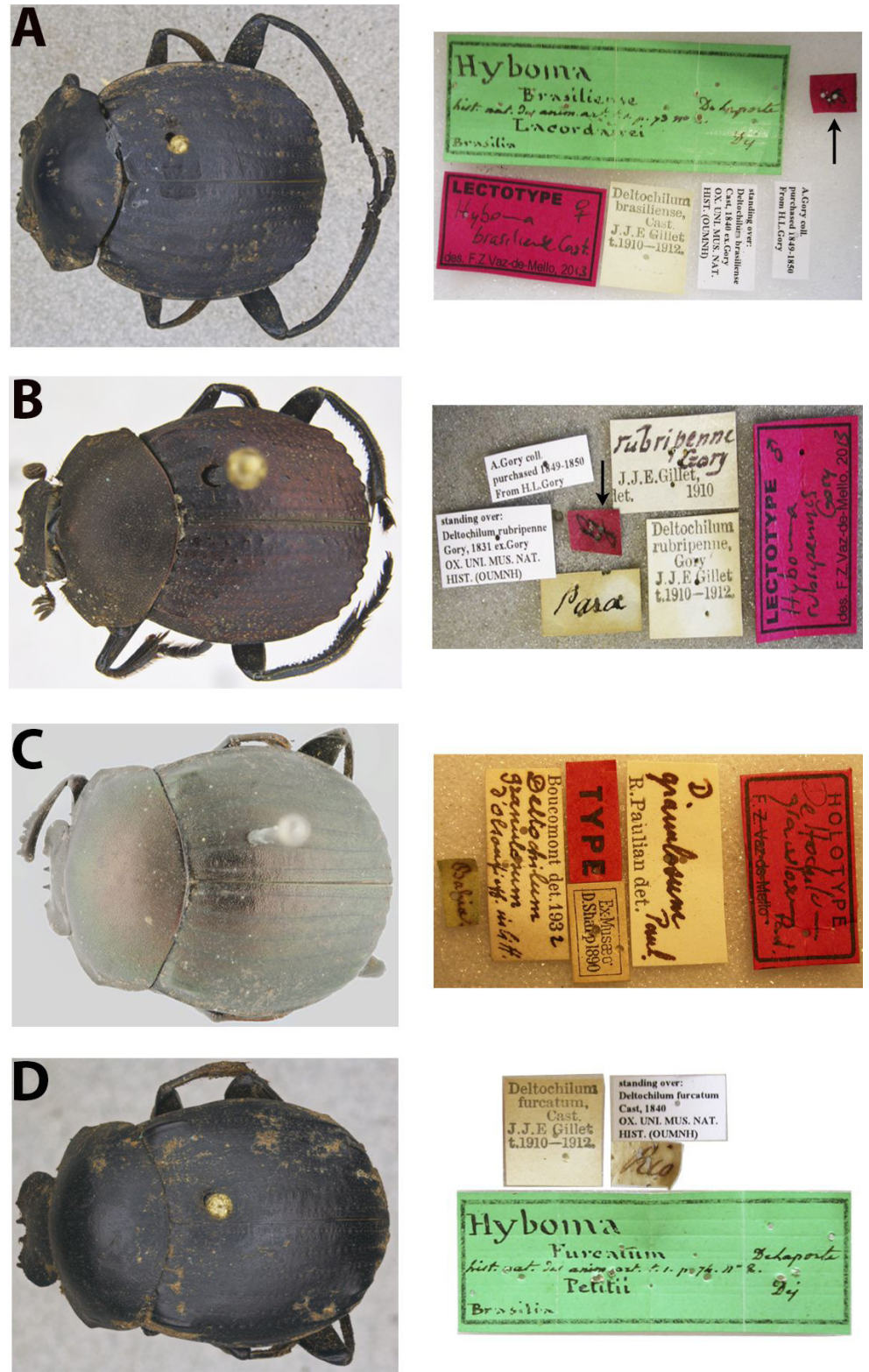

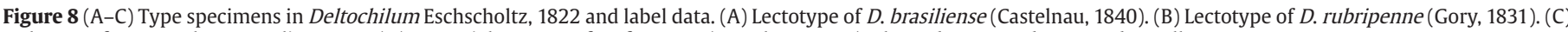
Holotype of $D$. granulosum Paulian, 1933. (D) Potencial syntype of $D$. furcatum (Castelnau, 1840). Photos by Fernando Z. Vaz-de-Mello.

136 (checklist); Krajcik, 2006: 48 (checklist); Silva et al., 2011: 336, 339 (identification key); Krajcik, 2012: 88 (checklist).

Deltochilum (Euhyboma) brasiliense: Kolbe, 1893: 192 (redescription); Paulian, 1938: 258, 259 (distribution and redescription); Lane, 1946: 174 (taxonomic remarks); Lange, 1947: 307 (checklist and distribution); Vulcano and Pereira, 1964: 646 (catalogue and distribution); Vaz-deMello, 2000: 192 (checklist); Medina et al., 2003: 65 (list of species and distribution); Vaz-de-Mello et al., 2011: 44 (checklist); Vaz-de-Mello, 2020 (checklist).

Euhyboma brasiliense: Shipp, 1897: 195 (taxonomic remarks)

Type material. Hyboma brasiliense Castelnau Lectotype $q$ (here designated; examined from photo; OUMNH): "Hybomal Brasiliense De Laporte| hist. nat. | Lacordairei D4| Brasilia" || "G” || “Deltochilum/ brasiliense, / Cast. / J.J. E Gillet/ t. 1910-1912" // "standing over/ Deltochilum brasiliense/ Cast, 1840 ex. Gory/ OX. UNI. MUS. NAT. / HIST. (OUMNH)" // "A. Gory coll/ purchased 1849-1850/ From H. L. Gory" // "LECTOTYPE f / Hyboma| brasiliense Cast. / des. F. Z. Vaz-de-Mello, 2013”.
Remarks. In the original description, Castelnau (1840) said that the material examined by him was from Gory's collection. According to Cambefort (2006), Gory's personal collection was scattered throughout different museums in Europe. Specimens from Gory's collection can be generally recognized by the presence of a small red square label handwritten ' $G$ ' attached to them (Maldaner et al., 2017). A specimen bearing such a ' $G$ ' label and that, at the same time, matches the definition of Hyboma brasiliense given by Castelnau (1840) in the original description ("Long. 9 lig. Larg. 7 lig.; élytres avec une carène oblique, et partagée en cinq petites côtes, placée prés de l'extrémité"), and from the original type locality (Brazil) was found in OUMNH collection (Fig. 8A), one of the main museums where Gory's specimens can be found (Maldaner et al., 2017). Therefore, we are confident in considering this specimen a syntype and designate it as the lectotype of $D$. brasiliense in accordance with Article 74 (specifically 74.1.1 and 74.7) of the ICZN (1999), with the purpose of maintaining nomenclatural stability.

Non-type material examined. ARGENTINA: MISIONES, Caianguás, Dos de Mayo, $\left[27,036284^{\circ} \mathrm{S}-54,675559^{\circ} \mathrm{W}\right], 08 . \mathrm{I} .1990$, no collector 
- 2 unsexed specimens (CEMT); same data but, XI.2007, E. Abadie leg. - 1 unsexed specimen (CEMT); Eldorado, [26,399919 ${ }^{\circ} \mathrm{S}-54,626812^{\circ}$ W], XII.1994, J. D’Alessandro leg. - 2 unsexed specimens (CEMT); Urugua-Í River, Reserva Fundación Vida Silvestre Argentina, [26 ${ }^{\circ} 1,0225^{\prime}$ S - 54 1,0064' W], 365m, 05-12.II.2014, G. Zurita, A. Gómez and V. Gimenez leg. - 1 unsexed specimen (CEMT); same data but, [26 ${ }^{\circ} 1,0345^{\prime}$ S - 54 9 9,579' W], 298m, G. Zurita, A. Gómez and V. Gimenez leg. - 1 unsexed specimen (CEMT). BRAZIL: [no locality data, $1 \lesssim$ IRSN]; BAHIA, Porto Seguro, [16,446838 $\left.{ }^{\circ} \mathrm{S}-39,071079^{\circ} \mathrm{W}\right]$, VII.1986, no collector - 1 unsexed specimen (CEMT); Wenceslau Guimarães, [13 41' 21" S - 39 21' 52" W], 146m, C. Leite leg. - 1 unsexed specimen (CEMT); Wenceslau Guimarães, [13³4' 32" S - 39 42' 25” W], 146m, I.2011, C. Leite leg. - 2 unsexed specimens (CEMT). ESPIRITO SANTO, Conceição do Castelo, [20,364387 ${ }^{\circ} \mathrm{S}-41,242121^{\circ}$ W], II. 1994, A. Grossi and F. Vaz-de-Mello leg. -2 unsexed specimens (CEMT); Marechal Floriano, [20,441979 ${ }^{\circ} \mathrm{S}$ - 40,776661 ${ }^{\circ}$ W], I.2003, L. Dias leg. - 1 unsexed specimen (CEMT); Santa Maria de Jetibá, Rio Lamego ("Rio Lameco"), 800 m, II.1959, no collector - 1 오 (DZUP); Santa Teresa ("STA Tereza), 07.XII.1964, C. Elias leg. - 1 ( (DZUP); Vargem Alta, [20,674002 S - 41,009821 W], IX.1995, J. Louzada leg. -1 unsexed specimen (CEMT); Venda Nova do Imigrante, [20,327507 $\left.\mathrm{S}-41,135935^{\circ} \mathrm{W}\right]$, I.1998, Falqueto and F. Vaz-de-Mello leg. - 1 unsexed specimen (CEMT). MINAS GERAIS, Aiuruoca [atlantic forest], [21 $58^{\prime} 31^{\prime \prime} \mathrm{S}-44^{\circ} 36^{\prime} 12^{\prime \prime} \mathrm{W}$ ], 21.III.2010, pitfall with dung,

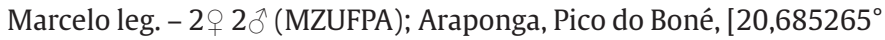
S - 42,452683 ${ }^{\circ} \mathrm{W}$ ], 17.XII.2000, E. Stehling leg. - 2 unsexed specimens (CEMT); Barbacena, Campus IFET-Sudeste, [21 ${ }^{\circ} 14^{\prime}$ 9,63" S - 43 45,6' 55" W], 20.XI.2012, F. Gomes leg. - 1 unsexed specimen (CEMT); Carrancas, Chapada dos Perdizes, [21 ${ }^{\circ} 38^{\prime} 15^{\prime \prime}$ S - 44 35' 54" W], II.2010, no collector - $1{ }^{\lambda}$ (MZUFPA); Itamonte [atlantic forest], [ $22^{\circ} 21^{\prime} \mathrm{S}-44^{\circ}$ 47' W], 1737m, 13.X.2009, pitfall with dung, V. Oliveira leg. $-1 \delta^{\lambda}$ (MZUFPA); Lima Duarte, Parque Estadual do Ibitipoca, [21,711972 ${ }^{\circ} \mathrm{S}$ - 43,903014 ${ }^{\circ}$ W], VI.2001, F. Vaz-de-Mello leg. - 1 unsexed specimen (CEMT); Prados, Área de Proteção Ambiental São José [savanna], [21 ${ }^{\circ}$ 3' 2" S - 44 9' 0" W], 1,045m, 16.I.2012, pitfall with human dung, L. Vieira leg. - 2 unsexed specimens (CEMT); Prados, Área de Proteção Ambiental São José [seasonal semideciduous atlantic forest], [21 ${ }^{\circ}$ ' 13,1" S - 44 7' 4" W], 1,159m, 17.II.2012, pitfall with rotten meat, L. Vieira leg. - 1 unsexed specimen (CEMT); same data but, [21 ${ }^{\circ}$ ' 51,9" S - 44 ${ }^{\circ}$ ' 59" W], 1,230m, 14.III.2012, pitfall with rotten meat, L. Vieira

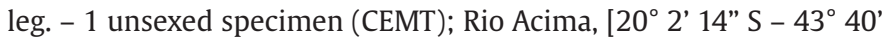
54" W], 05.XII.2007, E. Bordoni leg. - 1 unsexed specimen (CEMT); São João Evangelista [forest in rainy season], [ $18^{\circ} 33^{\prime} 11^{\prime \prime} \mathrm{S}-42^{\circ} 53^{\prime} 58^{\prime \prime}$ W], 898m, 02.IV.2011, human dung, R. Mota leg. - 1 unsexed specimen (CEMT); same data but, [18 34' 9" S - 42 53' 4" W], 856m, 02.IV.2011, human dung, R. Mota leg. - 1 unsexed specimen (CEMT); Viçosa, [20,754870 $\left.\mathrm{S}-42,878586^{\circ} \mathrm{W}\right], 16 . X I I .1993$, J. Louzada leg. -2 unsexed specimens (CEMT); same data but, 07.I.1994, J. Louzada leg. - 1 unsexed specimen (CEMT); same data but, II.1994, J. Louzada leg. - 1 unsexed specimen (CEMT); same data but, 02.II.1994, J. Louzada leg. - 4 unsexed specimens (CEMT); same data but, XII.1998, F. Vaz-de-Mello leg. - 1 unsexed specimen (CEMT); Viçosa, Mata de São Geraldo, [20,754870 ${ }^{\circ}$ S - 42,878586 ${ }^{\circ}$ W], XII. 1995, pitfall, J. Louzada and F. Vaz-de-Mello leg. - 1 unsexed specimen (CEMT). PARANÁ, Londrina, [23,304452 ${ }^{\circ} \mathrm{S}$ - 51,169582 ${ }^{\circ}$ W], XI.1998, I. Medri leg. - 1 unsexed specimen (CEMT); Ortigueira, XI.1945, Ernesto leg. - 1 + (DZUP - ex F. Justus Jor collection);

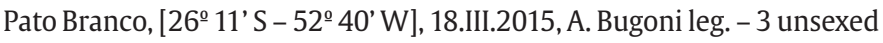
specimens (CEMT); Piraquara, Banhado, 28.XII.1970, S. Paroca (?) leg. - 1 q (DZUP); Piraquara, Parque Estadual Pico do Marumbi, Mananciais da Serra, 09.XII.2011, F. Leivas, P. Grossi and K. Milke leg. - $2 \widehat{\jmath}$ (DZUP); Tapejara, I.1953, no collector - $1 \delta^{1} \uparrow$ (DZUP - ex F. Justus Jor collection); Tijuco Preto, Rio Negro, [26 3’ 43" S - 39 45' 53" W], V.2012, R. Marcolino leg. - 1 unsexed specimen (CEMT). PERNAMBUCO, Caruaru, Parque
Ecológico João Vasconcelos Sobrinho, [08,284964 S - 35,970187 W], 11.V.2008, C. Costa leg. - 1 unsexed specimen (CEMT). RIO DE JANEIRO,

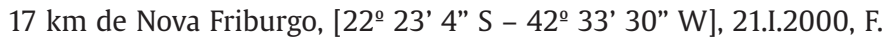
Génier and S. Ide leg. -1 unsexed specimen (CEMT); Itatiaia, [22,442824 ${ }^{\circ}$ S - 44,587844 W], XI.1991, C. Godinho leg. - 2 unsexed specimens

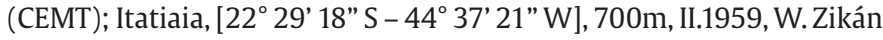
leg. -4 unsexed specimens (MNRJ); Itatiaia, km 13, [22 $23^{\circ} 47^{\prime \prime} \mathrm{S}-44^{\circ}$ 42' 15” W], 1,830m, 02.I.1927, J. Zikán leg. - 1 unsexed specimen (CEIOC); Itatiaia, Maromba, [22 19 ' 58” S - 44 36' 36” W], 1,100m, 28.XII.1925, J. Zikán leg. - 1 unsexed specimen (CEIOC); Itatiaia, Parque Nacional de Itatiaia, [22 $20^{\prime} 30^{\prime \prime} \mathrm{S}-44^{\circ} 34^{\prime}$ 59” W], 1,250m, 30.IX-02.X.2010, M. L. Monné and M. A. Monné leg. - 2 unsexed specimens (MNRJ);

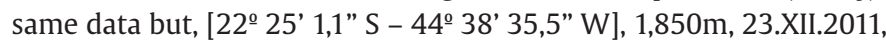
pitfall, C. Araújo and R. Andrade leg. - 9 unsexed specimens (CEMT);

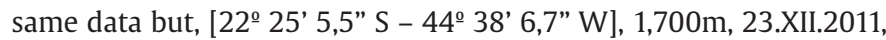
pitfall, C. Araújo and R. Andrade leg. - 4 unsexed specimens (CEMT);

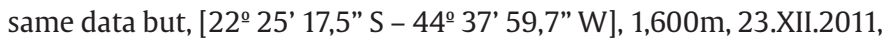
pitfall, C. Araújo and R. Andrade leg. - 3 unsexed specimens (CEMT);

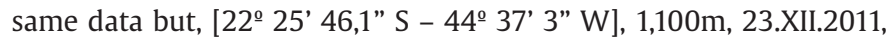
pitfall, C. Araújo and R. Andrade leg. - 2 unsexed specimens (CEMT); same data but, [22을ㄱ' pitfall, C. Araújo and R. Andrade leg. - 1 unsexed specimen (CEMT);

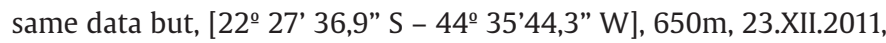
pitfall, C. Araújo and R. Andrade leg. - 1 unsexed specimen (CEMT);

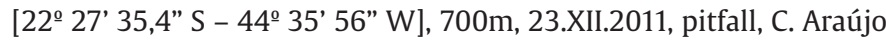
and R. Andrade leg. - 1 unsexed specimen (CEMT); Itatiaia, Parque Nacional de Itatiaia, near Casa do Pesquisador [ombrophilous forest], [ $22^{\circ} 27^{\prime} 15.9^{\prime \prime} \mathrm{S}-44^{\circ} 36^{\prime} 26.9^{\prime \prime} \mathrm{W}$ ], 810m, 22-25.II.2013, pitfall with rotten fish, M. Cupello leg. - 2 unsexed specimens (MNRJ); Nova Friburgo, [22,288726 $\left.{ }^{\circ} \mathrm{S}-42,534080^{\circ} \mathrm{W}\right]$, I.1995, F. Vaz-de-Mello leg. - 1 unsexed specimen (CEMT); Nova Friburgo, Casa Coelho, [22 ${ }^{\circ} 15^{\prime} 12^{\prime \prime} \mathrm{S}-42^{\circ} 36^{\prime}$ 42" W], I.1995, P. Filho leg. - 1 unsexed specimen (CEIOC); Teresópolis,

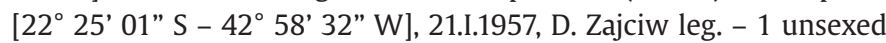
specimen (MNRJ); Teresópolis, Parque Nacional da Serra dos Órgãos,

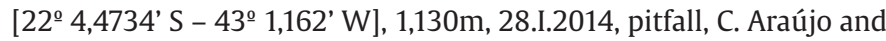
R. Andrade leg. - 1 unsexed specimen (CEMT); Teresópolis, Parque Nacional de Itatiaia, [22 ${ }^{\circ} 4,4721^{\prime} \mathrm{S}-43^{\circ} 8,9^{\prime} \mathrm{W}$ ], 1,280m, 28-30.I.2014, pitfall, C. Araújo and R. Andrade leg. - 1 unsexed specimen (CEMT); Teresópolis, Parque Nacional da Serra dos Órgãos, [22ํㅜ 4,4784' S - 43ํㅜㅇ 1,308' W], 1,380m, 28-30.I.2014, pitfall, C. Araújo and R. Andrade leg. - 2 unsexed specimens (CEMT); same data but, 1,400m, 16-18.XII.2014, pitfall, C. Araújo and R. Andrade leg. - 4 unsexed specimens (CEMT);

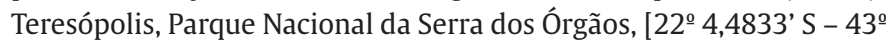
7,48’ W], 1,250m, 16-18.XII.2014, pitfall, C. Araújo and R. Andrade leg. - 2 unsexed specimens (CEMT); Teresópolis, Parque Nacional da Serra

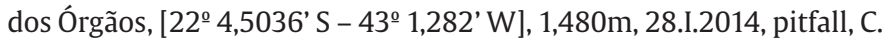
Araújo and R. Andrade leg. - 1 unsexed specimen (CEMT); same data but, 1,500m, 16-18.XII.2014, C. Araújo and R. Andrade leg. - 3 unsexed specimens (CEMT); Teresópolis, Parque Nacional da Serra dos Órgãos, [22ํㅗ 4,5350' S - 43ำ1,943’ W], 1,780m, 28-30.I.2014, pitfall, C. Araújo and R. Andrade leg. - 1 unsexed specimen (CEMT). RIO GRANDE DO SUL, Bento Gonçalves, [29,166709 ${ }^{\circ}$ - 51,516986 ${ }^{\circ}$ W], IX.2001, C. Arioli

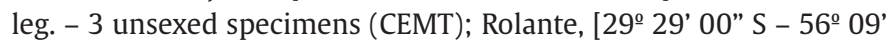
16" W], 19.X.2010, G. Viegas leg. - 1 unsexed specimen (CEMT); São Francisco de Paula, Floresta Nacional de São Francisco de Paula [mixed ombrophilous forest], [29²5' 21" S - 50²3' 12” W], 13.I.2008, L. Audino leg. - 11 unsexed specimens (CEMT); same data but, 14.I.2008, L. Audino leg. - 3 unsexed specimens (CEMT); São Francisco de Paula, Floresta Nacional de São Francisco de Paula [pine vegetation], [29 25' 21" S - 50²3' 12” W], 13.I.2008, L. Audino leg. - 5 unsexed specimens (CEMT); same data but, 14.I.2008, L. Audino leg. - 3 unsexed specimens (CEMT); São Francisco de Paula, Floresta Nacional de São Francisco de 
Paula [eucalyptus vegetation], [29² $\left.25^{\prime} 21^{\prime \prime} \mathrm{S}-50^{\circ} 23^{\prime} 12^{\prime \prime} \mathrm{W}\right]$, 13.I.2008, L. Audino leg. - 3 unsexed specimens (CEMT); São Francisco de Paula, Floresta Nacional de São Francisco de Paula, [29 $25^{\prime} 21^{\prime \prime}$ S - 50 $23^{\circ}$ ' 12" W], 10-13.XII.2009, P. Grossi leg. - 1 unsexed specimen (CEMT); São Francisco de Paula, Floresta Nacional de São Francisco de Paula [secondary forest], [29 28' 48” S - 50 10' 18” W], 20.II-19.III.2002, R. Ott leg.

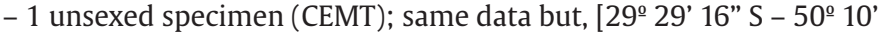
60" W], 20.II-19.III.2002, R. Ott leg. - 1 unsexed specimen (CEMT); São José do Ouro, $\left[27,772245^{\circ} \mathrm{S}-51,578115^{\circ} \mathrm{W}\right], 16 . X I .2013$, egg trap, E. Santos leg. - 1 unsexed specimen (CEMT); Taquara, [2924' 11" S 560 09' 01" W], 19.X.2010, G. Viegas leg. - 1 unsexed specimen (CEMT). SANTA CATARINA, Anitápolis, [27ํ5' S - 490ㅜㄱ' W], 28.I.2013, T. Simões leg. - 2 unsexed specimens (CEMT); Antonio Carlos, [27을 $25^{\prime} \mathrm{S}-48^{\circ}$ 51' W], 04.III.2013, J. Bogoni leg. - 1 unsexed specimen (CEMT);

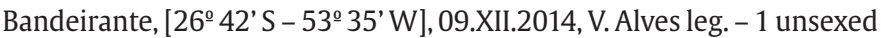
specimen (CEMT); Bom Jardim da Serra, Distrito Mantiqueira, [28,265982 ${ }^{\circ} \mathrm{S}$ - 49,762108 ${ }^{\circ}$ W], I. 2002, C. Arioli leg. - 1 unsexed specimen (CEMT);

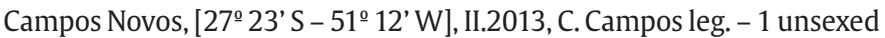

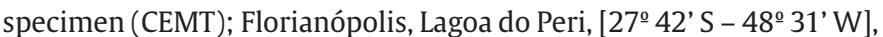
01.II.2013, pitfall, P. Silva leg. - 1 unsexed specimen (CEMT); Florianópolis,

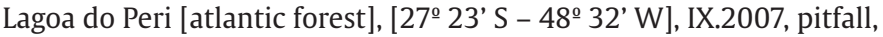
A. Martins and M. Hernández leg. - 1 unsexed specimen (CEMT); same data but, I.2008, pitfall, A. Martins and M. Hernández leg. - 1 unsexed specimen (CEMT); Florianópolis, Unidade de Conservação Ambiental Desterro, [27ํ 31' S - 48ํ 30' W], 09.I.2013, pitfall, P. Silva leg. - 1 unsexed

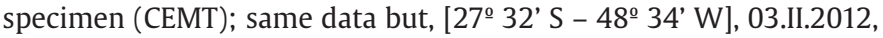
pitfall, P. Silva leg. - 1 unsexed specimen (CEMT); same data but, [27ํㅜㅇ 32' S - 48을 28 W], 24.II.2012, pitfall, P. Silva leg. - 1 unsexed specimen

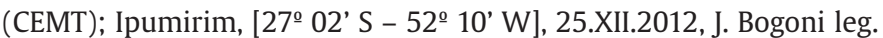
- 2 unsexed specimens (CEMT); Itapema, [27o 04' S - 48 $36^{\prime}$ 'W], 17.I.2013, P. Silva leg. - 1 unsexed specimen (CEMT); Monte Castelo

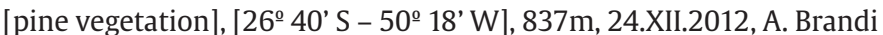
leg. - 1 unsexed specimens (CEMT); same data but, [26은 $41^{\prime} \mathrm{S}-50^{\circ} 18^{\prime}$ W], 810m, 24.XII.2012, A. Brandi leg. - 2 unsexed specimens (CEMT); Monte Castelo [atlantic forest], [26 $6^{\circ} 42^{\prime} \mathrm{S}-5^{\circ}{ }^{\circ} 19^{\prime} \mathrm{W}$ ], 1,116m, 06. VIII.2012, A. Brandi leg. - 2 unsexed specimens (CEMT); same data but,

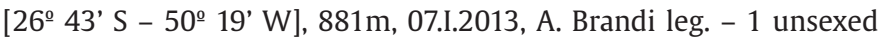

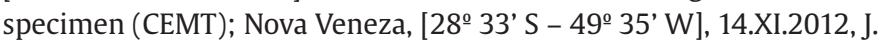
Bogoni leg. - 1 unsexed specimen (CEMT); same data but, 20.III.2013, J. Bogoni leg. - 1 unsexed specimen (CEMT); São Pedro de Alcântara, [27ํㅜㄱ' S - 48ํ5' W], 27.II.2013, J. Bogoni leg. - 1 unsexed specimen (CEMT); Seara, Pinhal, XII.1957, no collector - 1ð (DZUP); Romelândia,

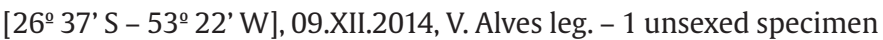
(CEMT); Santo Amaro da Imperatriz, Parque Estadual da Serra do

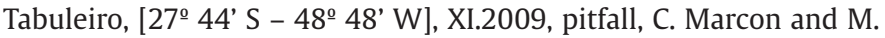
Hernández leg. - 2 unsexed specimens (CEMT); São Domingos, [26ㅜㅜ 26' S - 52ํ3' W], 27.VII.2011, J. Bogoni leg. - 1 unsexed specimen (CEMT); same data but, 28.XII.2011, J. Bogoni leg. - 1 unsexed specimen

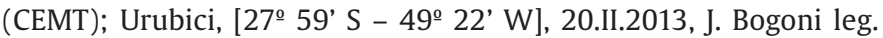
- 1 unsexed specimen (CEMT). SÃO PAULO, Caraguatatuba, [23,625590 S - 45,424145 ${ }^{\circ}$ W], 21.IX.2012, A. Diaz leg. - 1 unsexed specimen (CEMT);

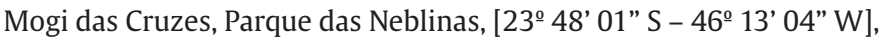
IX.2015, pitfall with human dung, R. Nunes leg. - 1 unsexed specimen (CEMT); Mogi das Cruzes, Parque das Neblinas [secondary forest], [23ํㅜㅇ 45' 49” S - 46울' 05” W], 24-28.III.2015, pitfall with human dung, R. Nunes leg. - 1 unsexed specimen (CEMT); Salesópolis, Estação Biológica de Boraceia, Serra do Mar, est. biol. 50km SE de Mogi das Cruzes, [23,722377 $\left.{ }^{\circ} \mathrm{S}-46,358181^{\circ} \mathrm{W}\right], 800-900 \mathrm{~m}, 28-30 . I V .1997$, dung trap, F. Génier and S. Ide leg. - 2 unsexed specimens (CEMT); same data but, rotten meat trap, F. Génier and S. Ide leg. - 2 unsexed specimens (CEMT); Salesópolis, Estação Biológica de Boraceia, [23ㅇ3' 20,1' S - 45ำ 53' 23,7” W], 18.IX.2012, pitfall, A. Diaz leg. - 1 unsexed specimen
(CEMT); São Miguel Arcanjo, Parque Estadual Carlos Botelho, [24ํㅜㅇ' 35" S - 47 58' 43" W], 785m, 20.XI.2011, Brachyteles sp. dung, E. Bovy

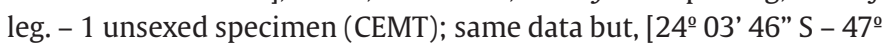
58' 44" W], 823m, 29.I.2012, human dung, E. Bovy leg. - 1 unsexed

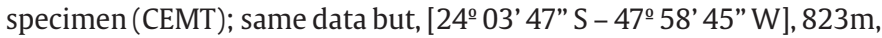
29.I.2012, human dung, E. Bovy leg. - 4 unsexed specimens (CEMT);

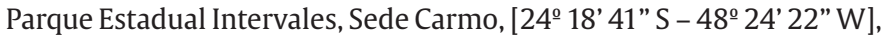
$598 \mathrm{~m}$, 26.III.2012, human dung, E. Bovy leg. - 1 unsexed specimen

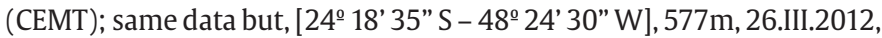
human dung, E. Bovy leg. - 1 unsexed specimen (CEMT); [24ํㅜ 18' 42" S - 48을 24' 25" W], 588m, 26.III.2012, human dung, E. Bovy leg. - 1 unsexed specimen (CEMT); Parque Estadual Intervales, Sede Ribeirão, [24ํㅜ 16' 40" S - 48 25' 54" W], 772m, 26.III.2012, human dung, E. Bovy leg. - 1 unsexed specimen (CEMT); Parque Estadual Serra do Mar, Núcleo

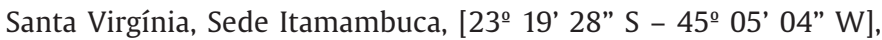
18.I.2012, human dung, E. Bovy leg. - 2 unsexed specimens (CEMT);

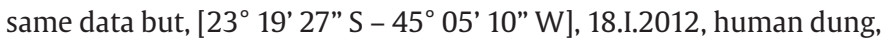
E. Bovy leg. - 1 unsexed specimens (CEMT); same data but, [23 $13^{\circ} 30^{\prime \prime} \mathrm{S}$ - 45 05' 00" W], 18.I.2012, human dung, E. Bovy leg. - 1 unsexed

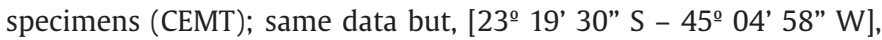
18.I.2012, human dung, E. Bovy leg. - 1 ( (CEMT); Parque Estadual Serra

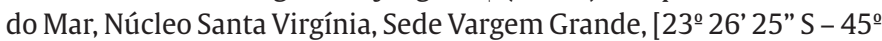
14' 19" W], 17.I.2012, human dung, E. Bovy leg. - 1 unsexed specimen

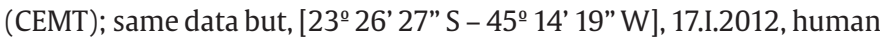
dung, E. Bovy leg. - 1 unsexed specimen (CEMT); same data but, [23을 26' 29" S - 451' 20" W], 17.I.2012, human dung, E. Bovy leg. - 1 unsexed

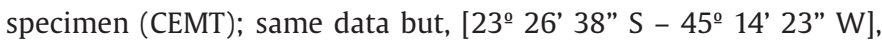
17.I.2012, human dung, M. Boutefeu leg. - 1 unsexed specimen (CEMT); same data but, [2326' 39" S - 451' 23” W], 17.I.2012, human dung, M. Boutefeu leg. - 1 unsexed specimen (CEMT); same data but, [23을 26' 40” S - 45ํ1' 25" W], 17.I.2012, human dung, M. Boutefeu leg.

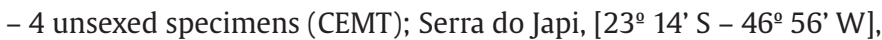
1998, M. Hernández leg. - 1 unsexed specimen (CEMT). PARAGUAY,

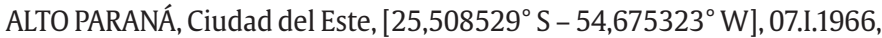
Zicsi leg - 1 unsexed specimen (CEMT).

Diagnosis. It differs from other species of Deltochilum by the following combination of characters: anterior portion of head, between clypeogenal sutures, subtrapezoidal, not prolonged in "muzzle" shape (Fig. 1B). Clypeus with an obtuse angle on its edge between clypeogenal suture and clypeal teeth (Fig. 1B). Ninth elytral interstria distinctly carinate (Fig. 1D). Carina of ninth interstria extending at most through the basal half of interstria (Fig. 1D). Pseudoepipleural carina lacking at base of elytra or inconspicuous (Fig. 1D). Lateral edge of elytra formed by the carina of ninth interstria at anterior half; posterior half formed by the pseudoepipleural carina. Fourth, fifth and sixth elytral interstriae with tubercles at base. Seventh interstria with thin and short carina at base. Elytral apex with carina at third, fourth, fifth, sixth and seventh interstriae. Protibiae with longitudinal row of conspicuous tubercles for about two-thirds of its ventral length. Body size longer than $20 \mathrm{~mm}$.

Redescription. Body. Dorsal surface black, anterior region convex (Fig. 2A). Ventral surface with greenish sheen. Body surface with dense granulation, visible at high magnification (Fig. 1C). Length. 22 to $26 \mathrm{~mm}$. Head. Foveiform punctures and microtubercles spaced by approximately once or twice their diameter (Fig. 1B). Clypeal edge with two medial teeth (Fig. 1B). Clypeogenal suture well impressed. Thorax. Pronotum with dense microtubercles and foveiform punctures, punctures denser at lateral edges. Pronotum with small depression close to lateral angles. Anteromedial surface of pronotum higher than surrounding surface. Anterior angles acute, directed forward. Hypomera not excavated, with foveiform punctures evenly distributed along the surface. Metaventrite with excavation near to posterior edge. Metaventrite punctures variable in size; smaller along anterior region, 
and larger at lateral edges, mesepimeron and metanepisternum. Elytra. Punctures of elytral striae spaced by approximately once or twice their diameter. Surface of interstriae with microtubercles and foveiform punctures; microtubercles more conspicuous in comparison to other body parts, giving a shiny aspect along surface. Ninth elytral interstria distinctly carinate (Fig. 1D). Carina of ninth interstria extending at most through the basal half of interstria (Fig. 1D). Pseudoepipleural carina lacking at base of elytra or inconspicuous (Fig. 1D). Lateral edge of elytra formed by the carina of ninth interstria at anterior half; posterior half formed by the pseudoepipleural carina. Fourth, fifth and sixth elytral interstriae with tubercles at base. Seventh interstria with thin and short carina at base. Elytral apex with carina at third, fourth, fifth, sixth and seventh interstriae. Abdomen. Punctures large and conspicuous on lateral surface of ventrites; denser along anterior edge of sixth ventrite. Pygidium densely punctate, rounded apically. Legs. Medial lateral tooth of protibia closer to apical tooth than to basal tooth. Dorsal surface of protibia with a longitudinal row of tubercles. Profemur wider at basal half, densely punctate. Punctures of meso and metafemur small and sparse. Meso and metatarsomeres 1-4 trapezoid, the last subrectangular shaped. Sexual dimorphism. Females can be distinguished from males, in general, by the tubercles at anterior edge of excavation of metaventrite absent (in males, two tubercles at anterior edge of excavation); first abdominal ventrite expanded mediallly, slightly compressing ventrite II (Fig. 2C) [in males, first abdominal ventrite strongly expanded medially, compressing at least ventrites II, III, and IV (Fig. 2D)]; surface of first abdominal ventrite regular, lacking carinae (Fig. 2C) [in males, first ventrite with two diagonal carinae delimiting a higher portion at abdominal surface (Fig. 2D)]; last abdominal ventrite evenly wide (in males, ventrite subtly narrower medially); protibial spur acute at apex (Fig. 2G) [in males, spur rounded at apex (Fig. 2H)]; posterior edge of metatrochanter regular, lacking expansion (in males, posterior edge of metatrochanter expanded towards the abdominal ventrites, spur-shaped); metafemur substraight (in males, metafemur curved anteriorly along its proximal third); metatibia straight along its proximal third, lacking lobes at apical third (Fig. 2E) (in males, metatibia curved outward along its proximal third, with two lobes at apical third (Fig. 2F). Tegmen. Parameres symmetrical, subtriangular in lateral view, shorter than phallobase, rounded at apex (Fig. 6A). Endophallus. Lamella Copulatrix (LC) (Fig. 7A). Left lobe subrectangular (Fig. 7A); right lobe trapezoid, with approximately the the same length as the left lobe (Fig. 7A). Superior Right Peripheral (SRP) endophallite with circular ring, and L-shaped cable (Fig. 7A); circular ring stuck to half the cable length. Frontolateral Peripheral (FLP) endophallite M-shaped (Fig. 7A). Complex of Axial and Subaxial (A+SA) endophallites elongate, irregular (Fig. 7A).

Biogeographical regions. Parana dominion (Atlantic, Parana and Araucaria forest provinces) and Chaco dominion (Pampa province) (see Morrone, 2014: fig. 12).

Distribution. Known from Brazil: Pernambuco, Bahia, Espírito Santo, Minas Gerais, Rio de Janeiro, São Paulo, Paraná, Santa Catarina, and Rio Grande do Sul); Argentina (Misiones); and Paraguay (Alto Paraná) (Fig. 9). From the label data, it seems that Deltochilum brasiliense inhabits the biogeographic dominions of Parana and Chaco along the Atlantic rainforest of Brazil, Argentina, and Paraguay. It was also reported from Colombia (Paulian, 1938; Pessôa and Lane, 1941; Vulcano and Pereira, 1964). However, it is clear that the records from Colombia represent either mislabeled or misidentified specimens. In addition to the data listed here, the species was also recorded in Brazil from Serra do Caraça and Passa Quatro (Minas Gerais), Cantagalo (Rio de Janeiro), Rio Pardo (São Paulo), and Piraquara (Paraná) by Pessôa and Lane (1941), Paulian (1938), Lange (1947), and Vulcano et al. (1980).

\section{Deltochilum (Parahyboma) Paulian, 1938}

Deltochilum (Parahyboma) Paulian, 1938: 243, 266 (original description, identification key, and taxonomic remarks); Lane, 1946: 175 (taxonomic remarks); Pereira and Martínez, 1956: 121, 125 (catalogue and identification key); Vulcano and Pereira, 1964: 650 (catalogue); Halffter and Matthews, 1966: 261 (checklist and distribution); Halffter and Edmonds, 1982: 139 (checklist and distribution); Vaz-de-Mello, 2000: 192 (checklist); Medina et al., 2003: 65 (list of species and distribution); Vaz-de-Mello et al., 2011: 5, 11, 18, 26, 33, 41, 44, 56 (checklist and identification key); Vaz-de-Mello, 2020 (checklist).

Diagnosis. It differs from other subgenera by having clypeus quadridentate; medial teeth more acute than lateral teeth. Posterior surface of metaventrite lacking tubercles. Ninth elytral interstria distinctly carinate at anterior portion (Fig. 1E). Carina of ninth interstria extending at most through the anterior half of interstria (Fig. 1E). Pseudoepipleural carina distinct at base (Fig. 1E).

Redescription. Body. Densely granulated, visible at high magnification. Length. 15 to $17 \mathrm{~mm}$. Head. Foveiform punctures and microtubercles spaced by approximately once or twice their diameter; punctures can be large or small near to clypeus. Clypeus with four teeth. Medial teeth more acute than lateral teeth. Cypeal teeth with setae at base. Thorax. Pronotum with foveiform punctures; denser at lateral portions and spaced by approximately three or four times their diameter at pronotal disc. Pronotum with small depression close to lateral angles; anterior angles acute, directed forward. Lateral edge of pronotum angulated; angle can be strongly or weakly expanded outward. Hypomera not excavated, with dense foveiform punctures on anterior portion; punctures on posterior portion denser at internal and external edges. Metaventrite with excavation near to posterior edge. Metaventrite punctures variable in size; smaller at anterior region and larger at lateral edges, metanepisternum and mesepimeron. Elytra. Punctures of elytral striae spaced by once or twice their diameter. Sixth interstria with inconspicuous carina at base. Seventh interstria carinate at base. Basal carina of ninth interstria with approximately one-third of elytral length, almost reaching the pseudoepipleural carina in some specimens. Elytra carinate at apex of first, third, fifth, sixth and seventh interstriae. Abdomen. Punctures denser at lateral surface of ventrites. Pygidium rounded at apex, densely punctate, and with spaced microtubercles along its surface. Legs. Medial lateral tooth of protibia closer to apical tooth than to basal tooth. Protibial teeth with setae at base. Dorsal surface of protibia with a longitudinal row of tubercles. Apex of protibia with setae. Surface of profemur with rounded or elliptical foveiform punctures. Meso and metafemur with small and sparse punctures. Longitudinal carinae of meso and metatibiae with row of setae. Meso and metatarsomeres 1-4 trapezoid, the last subrectangular. Sexual dimorphism. Females can be distinguished from males, in general, by the last abdominal ventrite evenly wide; in males, ventrite is subtly narrower at the middle; protibial spur acuminate at apex (Figs 3C, 4C); in males, spur rounded at apex (Figs 3D, 4D); half apical of mesotibia evenly straight, lacking expansion; in males, with abrupt expansion at half apical of mesotibia. Tegmen. Parameres symmetrical, subrectangular in lateral view (Fig. 6B, 6C). Endophallus. Superior Right Peripheral (SRP) endophallite with circular ring and L-shaped cable (Figs 7B-C); circular ring stuck to $2 / 3$ the cable length. Frontolateral Peripheral (FLP) endophallite, and Complex of Axial and Subaxial (A+SA) endophallites elongate, irregular (Figs 7B-C).

\section{Deltochilum (Parahyboma) furcatum (Castelnau, 1840)}

(Figs 1E, 3A-H, 6B, 7B, 8B)

Hyboma furcatum Castelnau, 1840: 74 (original description); Pereira and Martínez, 1956: 125 (cited as type species) 


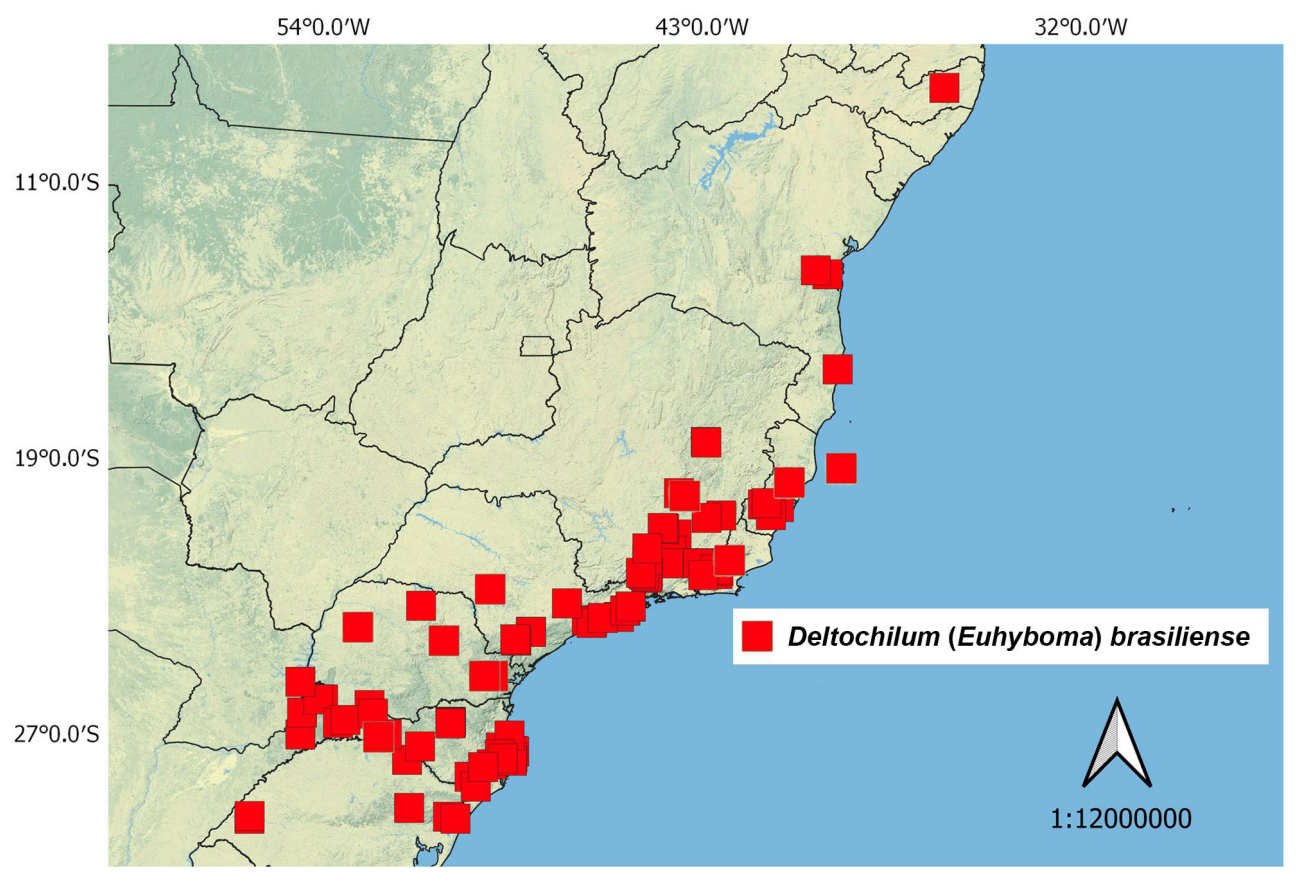

Figure 9 Collecting records of subgenus Deltochilum (Euhyboma) Kolbe, 1893.

Deltochilum furcatum: Burmeister, 1848: 135 (distribution and redescription); Redtenbacher, 1868: 54 (checklist); Harold, 1869: 995 (catalogue and distribution); Harold, 1875: 60 (taxonomic remarks); Gillet, 1911: 36 (catalogue); Pessôa and Lane, 1941: 429, 433 (catalogue, description, distribution, and identification key); Blackwelder, 1944: 202 (checklist and distribution); Krajcik, 2006: 48 (checklist); Krajcik, 2012: 88 (checklist).

Deltochilum (Parahyboma) furcatum: Paulian, 1938: 266, 267 (distribution, identification key, redescription, and taxonomic remarks); Lane, 1946: 175 (taxonomic remarks); Vulcano and Pereira, 1964: 650, 651 (catalogue and distribution); Vaz-de-Mello, 2000: 192 (checklist); Medina et al., 2003: 65 (list of species and distribution); Vaz-de-Mello, 2020 (checklist).

Type material. Unknown to us. Type locality: Brazil (Castelnau, 1840). Castelnau (1840) also said that the material examined of $D$. furcatum was from Gory's collection. As already mentioned in remarks section of $D$. brasiliense, Gory's collection was scattered throughout different museums in Europe, its specimens being generally recognized by the presence of a small red square label handwritten ' $G$ ' attached to them (Cambefort 2006; Maldaner et al., 2017). Unfortunately, Fernando Z. Vaz-de-Mello did not find specimens of $D$. furcatum with a label handwritten ' $G$ ' during his visits to several European museums between 2013 and 2014, including at OUMNH or at any other museum examined. However, he found an old specimen in OUMNH with the following label data: "Hyboma| Furcatum De Laporte/ hist. nat. | Petitii D4| Brasilia” |/ "Deltochilum/ furcatum, / Cast. / J. J. E Gillet/ t. 1910-1912” // "standing over/ Deltochilum furcatum/ Cast, 1840/ OX. UNI. MUS. NAT. / HIST. (OUMNH)" (Fig. 8D). We belive this specimen is potentially a syntype. However, as it does not bear a ' $G$ ' label, we prefer to follow the suggestion presented by Mario Cupello (referee) and, by now, we will not consider it as a syntype. Therefore, the whereabouts of the type series of $D$. furcatum remain unknown to us.

The application of the name furcatum to this Deltochilum species from southeastern of Brazil and northeastern of Paraguay and Argentina has long been well established (Paulian, 1938; Lane, 1946; Vulcano and
Pereira, 1964; Vaz-de-Mello et al., 2011), making no neotype designation necessary at the moment.

Non-type material examined. ARGENTINA: MISIONES, Caianguás, Dos de Mayo, [27,036284 $\left.{ }^{\circ} \mathrm{S}-54,675559^{\circ} \mathrm{W}\right]$, XI.2007, E. Abadie leg. - 2 unsexed specimens (CEMT); Iguazú, Puerto Esperanza, [26⒐9035’ S - 54ํㅜ 4,9178’ W], 03.III.2014, G. Zurita, A. Gómez and V. Gimenez leg. - 1 unsexed specimen (CEMT); Urugua-Í River, Reserva Fundación Vida Silvestre Argentina, [26오 9,8457’ S - 54ํㅜ 1,0375’ W], 05.II.2012, G. Zurita, A. Gómez and V. Gimenez leg. - 1 unsexed specimen (CEMT). BRAZIL: ESPIRÍTO SANTO, Santa Teresa, Reserva Biológica Augusto Ruschi, Trilha da Preguiça, [19 54’ 40” S - 40 32’ 29” W], 29.I.2015, T. Vargas leg. - 1 unsexed specimen (CEMT); Venda Nova do Imigrante, Lavrinhas, [20ำ 18' 16” S - 41ํ06' 58” W], I.2013, F. Vaz-de-Mello leg. - 2 unsexed specimens (CEMT). MINAS GERAIS, Aiuruoca [atlantic forest], [21 $58^{\prime} 31^{\prime \prime} \mathrm{S}$

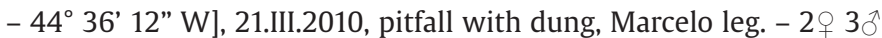
(MZUFPA); Araponga, Pico do Boné, $\left[20,685265^{\circ} \mathrm{S}-42,452683^{\circ} \mathrm{W}\right]$, 17.XII.2000, E. Stehling leg. - 1 unsexed specimen (CEMT); Barão de Cocais, Mina Gongo Soco [forest], [19² 57' 35” S - 43³5' 56” W], IX.2011, pitfall with dung, A. Murta leg. -1 우 $1 \delta^{\lambda}$ (MZUFPA); Barão de Cocais, Vale Mineração, [19 57’ 17” S - 43ํ3’ 51” W], 04.XI.2011, R. Mota leg. - 1 unsexed specimen (CEMT); Belo Horizonte, [19 $55^{\prime} 00^{\prime \prime} \mathrm{S}-43^{\circ} 56^{\prime}$ 04" W], I.1957, Machado leg., 1 오 (DZUP - M. Alvarenga collection); Conceição dos Ouros, [22,435106 ${ }^{\circ} \mathrm{S}-45,771056^{\circ}$ W], I.2003, G. Almeida leg. - 1 unsexed specimen (CEMT); Conceição dos Ouros, Rio Sapucaí, [22,435106 $\left.{ }^{\circ} \mathrm{S}-45,771056^{\circ} \mathrm{W}\right], 28 . I I .1995$, G. Almeida leg. -1 unsexed specimen (CEMT); Prados, Área de Proteção Ambiental São José [seasonal

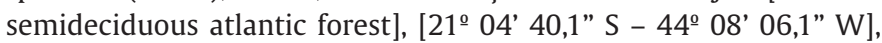
$1,090 \mathrm{~m}, 16 . \mathrm{I} .2012$, pitfall with human dung, L. Vieira leg. - 1 unsexed

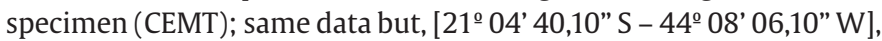
$1,090 \mathrm{~m}, 17 . \mathrm{II} .2012$, pitfall with rotten meat, L. Vieira leg. - 1 unsexed

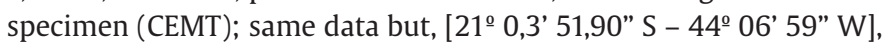
$1,230 \mathrm{~m}, 14 . \mathrm{III} .2012$, pitfall with human dung, L. Vieira leg. -1 unsexed

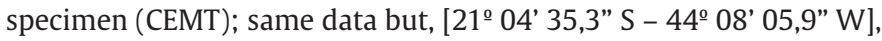
1,109m, 14.III.2012, pitfall with human dung, L. Vieira leg. -1 unsexed specimen (CEMT); Prados, Serra de São José [forest], [21 $06^{\circ} 05^{\prime \prime} \mathrm{S}-44^{\circ}$ $11^{\prime} 41$ " W], I.2012, pitfall with rotten meat, L. Vieira leg. - 1 ㅇ (MZUFPA); 
same data but, pitfall with dung, L. Vieira leg. - 1 q (MZUFPA); Viçosa, $\left[20,754870^{\circ} \mathrm{S}-42,878586^{\circ} \mathrm{W}\right], 28 . X I .1990$, Melo and Louzada leg. - 1 unsexed specimen (CEMT); same data but, 18.XII.1990, Louzada and Melo leg. - 1 unsexed specimen (CEMT); same data but, 11.I.1991, Lopes and Louzada leg. - 1 unsexed specimen (CEMT); same data but, 16.V.1991, Louzada and Melo leg. - 1 unsexed specimen (CEMT); same data but, 02.X.1991, Lopes and Louzada leg. - 11 unsexed specimen (CEMT); same data but, 03.X.1991, Lopes and Louzada leg. - 6 unsexed specimens (CEMT); same data but, 04.X.1991, Lopes and Louzada leg. - 10 unsexed specimens (CEMT); same data but, 05.X.1991, Lopes and Louzada leg. - 9 unsexed specimens (CEMT); same data but, 20.XI.1991, Lopes and Louzada leg. - 7 unsexed specimens (CEMT); same data but, 22.XI.1991, J. Louzada leg. - 2 unsexed specimens (CEMT); same data but, 23.XI.1991, Lopes and Louzada leg. - 1 unsexed specimen (CEMT); same data but, 11.I.1992, Lopes and Louzada leg. - 1 unsexed specimen (CEMT); same data but, 28.II.1992, Lopes and Louzada leg. - 3 unsexed specimens (CEMT); same data but, 27.III.1992, J. Louzada leg. - 1 unsexed specimen (CEMT); same data but, 10.I.1994, J. Louzada - 2 unsexed specimens (CEMT); same data but, 25.I.1994, J. Louzada leg. - 1 unsexed specimen (CEMT); same data but, 02.II.1994, J. Louzada leg. - 1 unsexed specimen (CEMT); same data but, 07.XII.1998, fly interception trap, J. Moreno and T. Mestre leg. - 2 unsexed specimens (CEMT); same data but, X.2000, pitfall, M. da Mata leg. - 1 unsexed specimen (CEMT); Viçosa, [20 45' 17" S - 42ํ5' 42” W], XII.1998, F. Vaz-de-Mello leg.

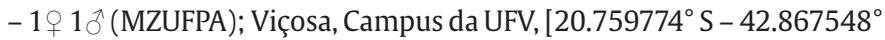
W], X.2000, pitfall, M. da Mata leg. - 14 unsexed specimens (CEMT); Viçosa, Mata da Biologia [atlantic forest], [20 $45^{\prime} 24^{\prime \prime} \mathrm{S}-42^{\circ} 51^{\prime} 38^{\prime \prime}$ W], 13.I.2010, pitfall with dung, L. Audino leg. - 1 ㅇ $1 \delta^{\curvearrowright}$ (MZUFPA); Viçosa, Mata da Biologia (Campus da UFV), [20 45' 28" S - 42 $51^{\circ}$ '55" W], 15.X.2011, close to the Diplopoda carcass, A. Puker leg. - 1 unsexed specimen (CEMT); Viçosa, Mata da Biologia, [20 $45^{\prime} 28^{\prime \prime} \mathrm{S}-42^{\circ} 51^{\prime}$ 55" W], 14.II.2015, pitfall, S. Aloquio and M. Bento leg. -3 unsexed

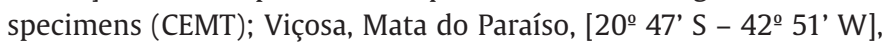
XII.1998, F. Vaz-de-Mello leg. - 109 unsexed specimens (CEMT); Viçosa, Mata do Paraíso, [20ํ 48’ 20,5” S - 42ํ51' 12,4” W], 781m, 03.V.2013, pitfall with dung, T. Vargas leg. - 2 unsexed specimens (CEMT); same data but, 28.I.2014, T. Vargas and L. Lopes leg. - 16 unsexed specimens (CEMT); Viçosa, Mata do Paraíso, [20,802319 S - 42,858630 W], 13.II.2015, S. Aloquio, A. Orsetti and C. Lopes-Andrade leg. - 1 unsexed specimen (CEMT); same data but, 19.II.2015, fly interception trap, S. Aloquio, A. Orsetti and M. Bento leg. - 2 unsexed specimens (CEMT);

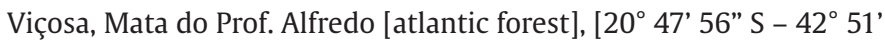
41" W], 17.I.2010, pitfall with dung, L. Audino leg. - 1ㅇ (MZUFPA). PARANÁ, Alto Paraná, [25 8,00515’ S - 54ํ3,8034’ W], 23.I.2013, G. Zurita - 1 unsexed specimen (CEMT); Altamira do Paraná, Estrada d'água da Bota, [24ํㅗㄴ 52' S - 42º 52' W], 21.III.2011, G. Weiss and P. Grossi leg. - 1 unsexed specimen (CEMT); Londrina, $\left[23,304452^{\circ} \mathrm{S}-51,169582^{\circ}\right.$ W], XI.1998, I. Medri leg. - 2 unsexed specimens (CEMT); Piraquara, Parque Estadual Pico do Marumbi, Mananciais da Serra, 09.XII.2011, F.

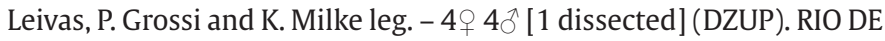
JANEIRO, 17 km de Nova Friburgo, [22 23' 04" S - 42우 33' 30" W], 23.I.2000, F. Génier and S. Ide leg. - 2 unsexed specimens (CEMT); Guapimirim, Parque Nacional Serra dos Órgãos, [22 $22^{\prime} 48^{\prime \prime} \mathrm{S}-43^{\circ}$ 00' 08” W], 750m, 16-18.XII.2014, C. Araújo and R. Andrade leg. - 3 unsexed specimens (CEMT); Itatiaia, $\left[22,442824^{\circ} \mathrm{S}-44,587844^{\circ}\right.$ W], I.1992, C. Godinho leg. - 1 unsexed specimen (CEMT); same data but, I.1993, E. Grossi leg. - 1 unsexed specimen (CEMT); Itatiaia, [22 ${ }^{\circ}$ 29' 28" S - 44 34' 19" W], 15.XII.1991, A. Bello leg. - 1 unsexed specimen

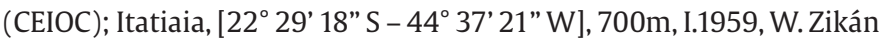

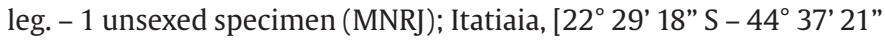
W], 700m, II.1959, W. Zikán leg. - 5 unsexed specimens (MNRJ); Itatiaia, Parque Nacional de Itatiaia, [ $\left.22^{\circ} 20^{\prime} 30^{\prime \prime} \mathrm{S}-44^{\circ} 34^{\prime} 59^{\prime \prime} \mathrm{W}\right], 1,250 \mathrm{~m}$,
30.IX-02.X.2010, M. A. Monné and M. L. Monné leg. - 7 unsexed

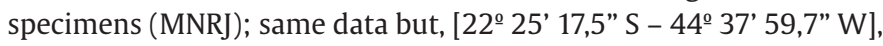
1,600m, 23-26.XII.2011, C. Araújo and R. Andrade leg. - 1 unsexed

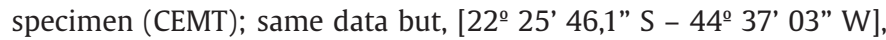
1,100m, 23-26.XII.2011, C. Araújo and R. Andrade leg. - 3 unsexed

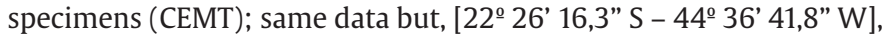
1,000m, 23-26.XII.2011, C. Araújo and R. Andrade leg. - 3 unsexed

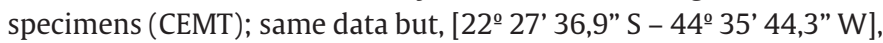
23-26.XII.2011, C. Araújo and R. Andrade leg. - 1 unsexed specimen (CEMT); Itatiaia, Parque Nacional de Itatiaia, near Casa do Pesquisador [ombrophilous forest], [22 27' 15" S - 44 36' 26" W], 810m, 22-24.X.2010, pitfall with human dung, W. Beiroz and M. Cupello leg. - 15 unsexed specimens (MNRJ); same data but, 11-13.XI.2011, pitfall with human dung, M. Cupello leg. - 7 unsexed specimens (MNRJ); same data but, 22-24.IX.2011, pitfall with human dung, M. Cupello leg. - 1 unsexed specimen (MNRJ); same data but, 27.II-01.III.2012, pitfall with human dung, M. Cupello leg. - 1 unsexed specimen (MNRJ); same data but, 22-25.II.2013, pitfall with rotten fish, M. Cupello leg. - 2 unsexed specimens (MNRJ); Nova Friburgo, [22,288726 $\left.{ }^{\circ} \mathrm{S}-42,534080^{\circ} \mathrm{W}\right]$, VI.1994, F. Vaz-de-Mello leg. - 1 unsexed specimen (CEMT); Rio de

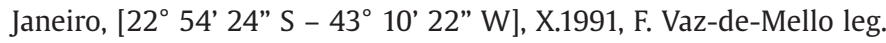
- 1 unsexed specimen (CEIOC); Rio de Janeiro, Corcovado, [22 $57^{\circ} 08^{\prime \prime} \mathrm{S}$

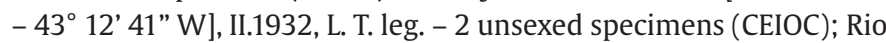
de Janeiro, Floresta da Tijuca, [22,959306 $\left.{ }^{\circ} \mathrm{S}-43,278462^{\circ} \mathrm{W}\right]$, XII. 1989, C. Godinho leg. -4 unsexed specimens (CEMT); Rio de Janeiro, Floresta da Tijuca, [22 57’ 26" S - 43 16’ 52” W], II.1937, C. Seabra leg. - 1 unsexed specimen (MNRJ); same data but, 29.I.1952, D. Zajciw leg. - 1 unsexed specimen (MNRJ); same data but, 29.I.1952, D. Zajciw leg. - 3 unsexed specimens (MNRJ); same data but, X.1979, C. Godinho leg. - 4 unsexed specimens (MNRJ); same data but, IX.1993, A. Serpa leg. - 3 unsexed specimens (MNRJ); same data but, 09.X.1993, V. Marchon leg. - 1 unsexed specimen (CEIOC); same data but, 17.X.1993, A. Serpa leg. - 4 unsexed specimens (CEIOC); Rio de Janeiro, Grajaú, [ $22^{\circ} 55^{\prime} 25^{\prime \prime} \mathrm{S}-43^{\circ} 15^{\prime} 30^{\prime \prime}$ W], IX.1965, H. Lopes leg. - 3 unsexed specimens (CEIOC); Rio de Janeiro, Jardim Botânico, [22,967372 ${ }^{\circ}$ S - 43,225038 W], XII.1992, F. Vaz-deMello leg. - 1 unsexed specimen (CEMT); Rio de Janeiro, Parque Lage,

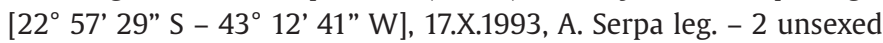
specimens (CEIOC); Teresópolis, Parque Nacional da Serra dos Órgãos,

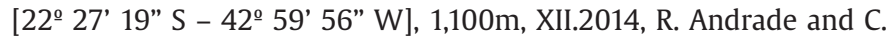
Araújo leg. - 12 unsexed specimens (CEMT); same data but, [22운,4721' S - 43ํ59' W], 1,300m, 16-18.XII.2014, C. Araújo and R. Andrade leg.

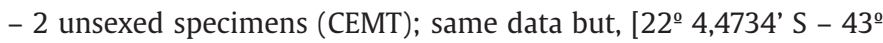
1,162' W], 1,330m, 28-30.I.2014, C. Araújo and R. Andrade leg. - 3 unsexed specimens (CEMT); same data but, [22 4,4784' S - 43ำ 1,308' W], 1,380m, 28-30.I.2014, C. Araújo and R. Andrade leg. - 2 unsexed

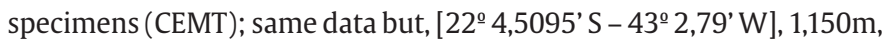
16-18.XII.2014, C. Araújo and R. Andrade leg. - 3 unsexed specimens

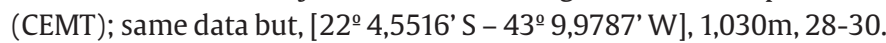
XII.2014, C. Araújo and R. Andrade leg. - 2 unsexed specimens (CEMT). SANTA CATARINA, Corupá, [26² 26' 07" S - 49¹4' 42" W], X.1966, A. Maller leg. - $1 \delta$ (DZUP); same data but, $60 \mathrm{~m}$, II.1958, no collector - $1 \hat{\partial}$ (DZUP); same data but, XI.1958, no collector - 1 (DZUP); SÃO PAULO, Parque Estadual Serra do Mar, Santa Virgínia, Sede Itamanbuca, [23

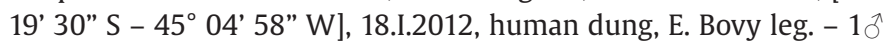

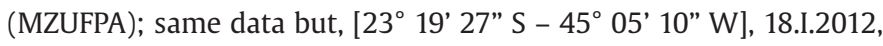
human dung, E. Bovy leg. - $1 \delta^{\AA}$ (MZUFPA); Salesópolis, Serra do Mar,

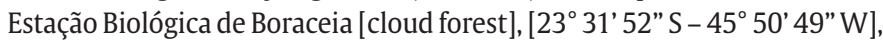
800-900m, 28-30.IV.1997, dung trap, F. Génier and S. Ide leg. - 1 ㅇ (MZUFPA); Serra do Japi, [23,236338 S - 46,943506 W], XII.1998, M. Medina leg. - 4 unsexed specimens (CEMT).

Diagnosis. It can be distinguished from $D$. (Parahyboma) granulosum by having the dorsal surface of the body black and opaque 
(Fig. 3A). Microtubercles of elytral interstriae elliptical and spaced by approximately once their diameter (Fig. 1G) (in D. granulosum, dorsal surface of the body light brown and shiny (Fig. 4A); microtubercles, in general, rounded, denser with microsculpture almost confluent (Fig. $1 \mathrm{H})$ ). The shape of parameres (Fig. 6B) and endophallites are also diagnosable among these species. In $D$. furcatum, apical projection of paramere shorter and more pointed (Fig. 6B) than that of D. granulosum (apical projection of paramere slightly rounded in the latter species (Fig. 6C)). Mid-apical region of the SRP cable strongly curved outward (Fig. 7B). Left lobe of Lamella Copulatrix "water drop" shaped. Right lobe subtriangular, shorter than the left lobe (Fig. 7B) (in D. granulosum, mid-apical region of the SRP cable curved in approximately 90 degrees (Fig. 7C). Left lobe of Lamella Copulatrix comma shaped (Fig. 7C). Right lobe subrectangular, curved, with approximately the same length as the left lobe (Fig. 7C)).

Sexual dimorphism. Females can be distinguished from males, in general, by the posterior edge of meso- and metafemur substraight, without angulation (in males, basal third of mesofemur with acute angle at posterior edge, and apical two-third of metafemur extended at posterior edge); internal portion of metatibia with longitudinal carina (Fig. 3E) [in males, metatibia with longitudinal row of tubercles (Fig. 3F)].

Biogeographical regions. Parana dominion (Atlantic, Parana and Araucaria forest provinces) (see Morrone 2014: fig. 12).

Distribution. Known from Brazil (Espírito Santo, Minas Gerais, Rio de Janeiro, São Paulo, Paraná, and Santa Catarina) and Argentina (Misiones) (Fig. 10). Vaz-de-Mello et al. (2011) cited the subgenus Parahyboma from Paraguay. We believe that this record refers to $D$. furcatum, since it is the only known species of the subgenus that occurs in areas close to Paraguay. Additionally, some regions of Paraguay have remnants of Atlantic forest, the ecosystem where the species inhabit. In addition, $D$. furcatum was also cited in Brazil from Cantagalo (Rio de Janeiro) and Salto Grande (São Paulo) by Paulian (1938) and Pessôa and Lane (1941).

\section{Deltochilum (Parahyboma) granulosum Paulian, 1933}

(Figs 4A-H, 6C, 7C, 8B)

Deltochilum granulosum Paulian, 1933: 204 (original description); Blackwelder, 1944: 202 (checklist); Krajcik, 2006: 48 (checklist); Krajcik, 2012: 88 (checklist).

Deltochilum (Parahyboma) granulosum: Paulian, 1938: 266, 267 (distribution, identification key, redescription, and taxonomic remarks); Vulcano and Pereira, 1964: 651 (catalogue and distribution); Vaz-de-Mello, 2000: 192 (checklist); Vaz-de-Mello, 2020 (checklist).

Type material. Deltochilum granulosum Paulian. Holotype (Fig. 8C) (examined from photos; MNHN): "HOLOTYPE/ Deltochilum/ granulosum/ Paul." |/ “D.| granulosum / Paul./ R. Paulian det." |/ "TYPE” // "Ex Musaeo/ D. Sharp 1890" // “Boucomont det. 1932/ Deltochilum/ granulosum/ D' Olsoufieff” // “Bahia”.

Non-type material. BRAZIL: BAHIA, Igrapiúna, Pacangê, [13ํ4' 08” S

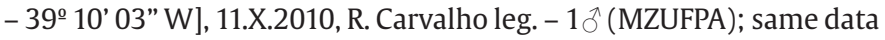

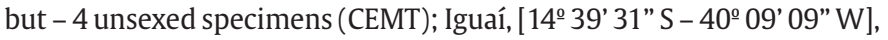
18.I.2012, C. Leite leg. - 2 unsexed specimens (CEMT); Porto Seguro, [16,446838 $\left.{ }^{\circ} \mathrm{S}-39,071079^{\circ} \mathrm{W}\right]$, VIII. 1989, E. Grossi leg. - 2 unsexed specimens (CEMT); same data but, VII. 1991, E. Grossi and P. Grossi leg. - 2 unsexed specimens (CEMT); same data but, VII. 1993, E. Grossi leg. - 1 unsexed specimen (CEMT); Porto Seguro, Reserva Particular do

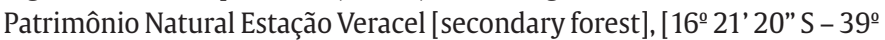
07' 09” W], 54m, 13.V.2012, rotten meat, L. Audino leg. - $1 \jmath^{\jmath}$ (MZUFPA); same data but - 1 unsexed specimen (CEMT); Porto Seguro, Reserva Particular do Patrimônio Natural Estação Veracel [secondary forest], [16을' 33" S - 390ㅜㅇ' 54" W], 94m, 20.V.2012, human dung, L. Audino leg. - 1 unsexed specimen (CEMT); Porto Seguro, Reserva Particular do Patrimônio Natural Estação Veracel [primary forest], [16우 19' 08" S - 390 06' 45” W], 15.V.2012, L. Audino leg. - 1 unsexed specimen

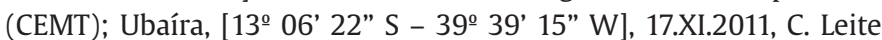
leg. - 1 unsexed specimen (CEMT); Wenceslau Guimarães, [13을' 32" S - 39을' 25" W], I.2011, C. Leite leg. - 1 unsexed specimen (CEMT); Wenceslau Guimarães [forest], [13,584708 S - 39,693091 W], 2013, C. Leite leg. -1 \% (MZUFPA); same data but -4 unsexed specimens (CEMT). ESPÍRITO SANTO, Barra de São Francisco, Córrego do Itá, [18 ${ }^{\circ}$ 45’ 16” S - 40 53’ 35” W], X.1954, W. Zikán leg. - 1ㅇ (DZUP - ex M. Alvarenga collection); Linhares, Reserva Natural Vale, [1909' 04" S $40^{\circ} 04^{\prime}$ 26" W], 14.X.2012, R. Lima leg. - 1 unsexed specimen (CEMT); Sooterama, Reserva Natural Vale, $\left[19,211639^{\circ} \mathrm{S}-40,093952^{\circ} \mathrm{W}\right]$, 02.II.2012, T. Vargas and L. Lopes leg. - 1 unsexed specimen (CEMT).

Diagnosis. It can be distinguished from $D$. (Parahyboma) furcatum by having the dorsal surface of the body light brown and shiny (Fig. 4A). Microtubercles of elytral interstriae, in general, rounded, denser with microsculpture almost confluent (Fig. $1 \mathrm{H}$ ) (in D. furcatum, dorsal surface of the body black and opaque (Fig. 3A); microtubercles elliptical and spaced by approximately once their diameter (Fig. 1G)). The shape of parameres (Fig. 6C) and endophallites are also diagnosable among these species. In D. granulosum, apical projection of parameres, in lateral and dorsal views, longer and slightly rounded (Fig. 6C) (in D. furcatum, apical projection of parameres shorter and pointed (Fig. 6B)). Mid-apical region of the SRP cable curved in approximately 90 degrees (Fig. 7C). Left lobe of Lamella Copulatrix comma shaped (Fig. 7C). Right lobe subrectangular, curved, with approximately the same length as the left lobe (Fig. 7C) (in D. furcatum, Mid-apical region of the SRP cable strongly curved outward (Fig. 7B). Left lobe of Lamella Copulatrix "water drop" shaped. Right lobe subtriangular, shorter than the left lobe (Fig. 7B)).

Sexual dimorphism. Females can be distinguished from males, in general, by the first elytral interstria with reduced carina at apex (Fig. 4E) (males with conspicuous carina on first elytral interstria apically (Fig. 4F)).

Biogeographical regions. Parana dominion (Atlantic and Parana provinces) (see Morrone 2014: fig. 12).

Distribution. Known from Brazil (Bahia and Espírito Santo) (Fig. 10).

\section{Deltochilum (Rubrohyboma) Paulian, 1939}

Deltochilum (Rubrohyboma) Paulian, 1938: 243 (identification key, nomen nudum); Paulian, 1939: 6 (original description and taxonomic remarks); Lane, 1946: 175 (taxonomic remarks); Pereira and Martínez, 1956: 120, 121 (catalogue and identification key); Martínez, 1959: 56 (catalogue); Vulcano and Pereira, 1964: 651 (catalogue); Halffter and Matthews, 1966: 261 (checklist and distribution); Halffter and Edmonds, 1982: 139 (checklist and distribution); Vaz-de-Mello, 2000: 192 (checklist); Medina et al., 2003: 65 (list of species and distribution); Krajcik, 2006: 47 (checklist); Vaz-de-Mello et al., 2011: 5, 11, 18, 25, 33, 40, 44, 56 (checklist and identification key); Krajcik, 2012: 88 (checklist); Vaz-de-Mello, 2020 (checklist).

Remarks. Paulian (1938) cited the name Rubrohyboma as a new subgenus, describing characters in an identification key. However, the author did not explicitly include a nominal species in the subgenus and a type species was not originally fixed. The Article 67.4.1 of the ICZN (1999) states that a nominal genus-group taxon established after 1930 must have its type species fixed in the original publication. Therefore, the name was not available in Paulian (1938). Only in 1939 Paulian described the subgenus Rubrohyboma to include D. rubripenne as the type species, making the name available.

Deltochilum (Rubrohyboma) rubripenne (Gory, 1831)

(Figs 1F, 5A-F, 6D, 7D, 8C) 


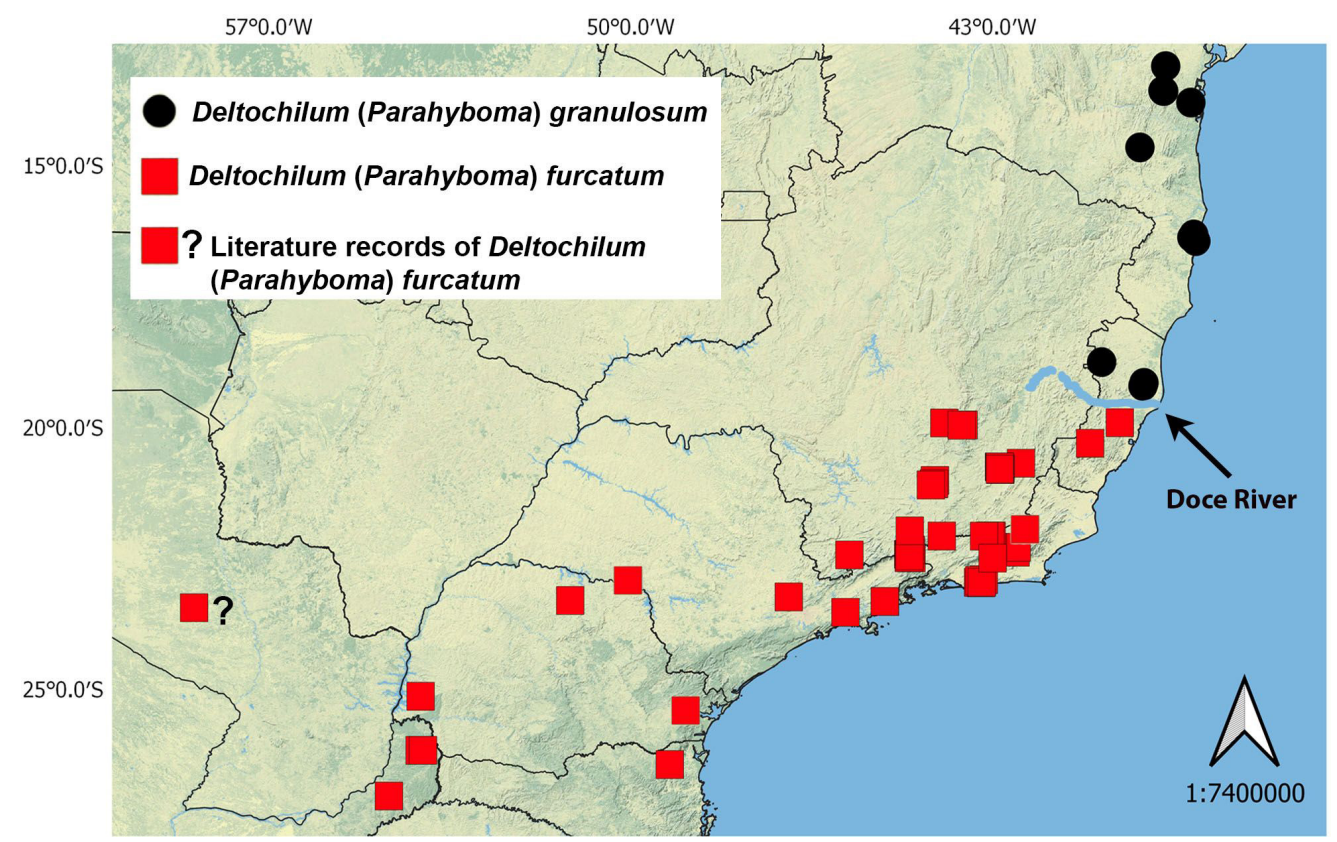

Figure 10 Collecting records of subgenus Deltochilum (Parahyboma) Paulian, 1938.

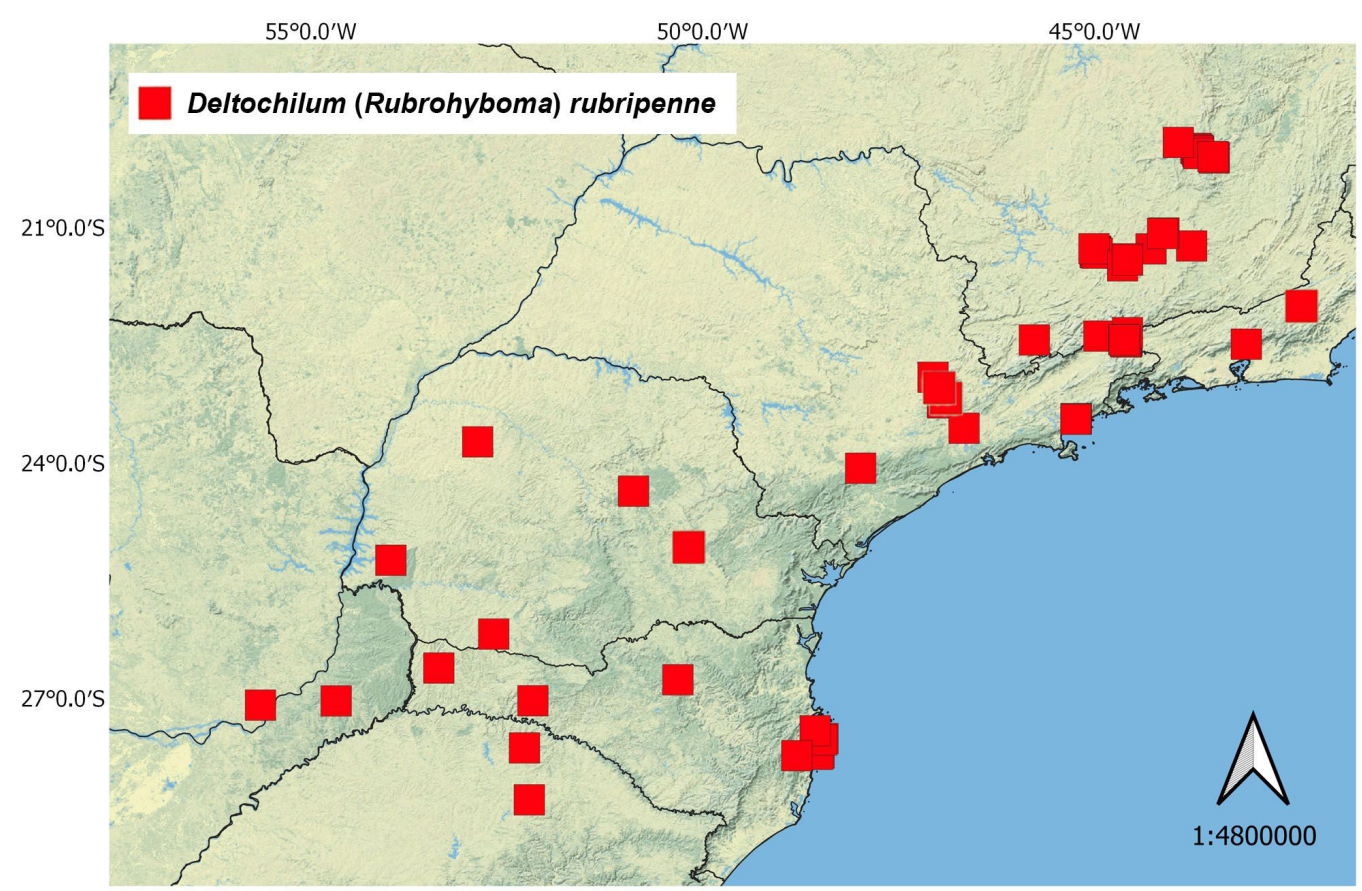

Figure 11 Collecting records of subgenus Deltochilum (Rubrohyboma) Paulian, 1938.

urn:lsid:zoobank.org:act:64564AFB-9D67-49ED-B429-66321C2EC59D

Hyboma rubripenne Gory, 1831: 37 (original description); Castelnau, 1840: 73 (redescription); Pereira and Martínez, 1956: 121 (cited as type species)

Deltochilum rubripenne: Burmeister, 1848: 135 (redescription); Harold, 1869: 995 (catalogue and distribution); Harold, 1875: 60 (taxonomic remarks); Bruch, 1911: 185 (checklist and distribution); Gillet, 1911: 36 (catalogue); Pessôa and Lane, 1941: 429, 435 (catalogue, description, distribution, identification key and taxonomic remarks); Blackwelder, 1944: 203 (checklist and distribution); Lange, 1947: 307 (checklist and distribution); Krajcik, 2006: 49 (checklist); Silva et al., 2011: 334, 339 (identification key); Krajcik, 2012: 88 (checklist).

Deltochilum (Rubrohyboma) rubripenne: Paulian, 1939: 6, 7 (distribution and redescription); Lane, 1946: 175 (taxonomic remarks); Martínez, 1959: 56 (catalogue and distribution); Vulcano and Pereira, 1964: 651, 652 (catalogue and distribution); Vaz-de-Mello, 2000: 192 (checklist); Medina et al., 2003: 65 (list of species and distribution); Vaz-de-Mello et al., 2011: 44 (checklist); Vaz-de-Mello, 2020 (checklist).

Type material. Hyboma rubripenne Gory Lectotype $\delta$ (here designated; OUMNH): “rubripenne/ Gory/ J. J. E Gillet/ det. 1910” // "Deltochilum/ rubripenne, / Gory/ J. J. E Gillet/ t. 1910-1912” // “Para” // 
"G" // "A. Gory coll./ purchased 1849-1850/ From H. L. Gory" // "standing over/ Deltochilum rubripenne/ Gory, 1831 ex. Gory/ OX. UNI. MUS. NAT. / HIST. (OUMNH)" // "LECTOTYPE Ő' Hybomal rubripenne/ Gory/ des. F. Z. Vaz-de-Mello, 2013".

Remarks. As already mentioned, specimens from Gory's collection can be generally recognized by the presence of a small red square label handwritten ' $G$ ' attached to them (Cambefort, 2006; Maldaner et al., 2017). A specimen with a Gory's label handwritten ' $G$ ' and that, at the same time, largely matches the description of Hyboma rubripenne given by Gory (1831) ("corpore nigro-cærulescenti, capite thoraceque fusco-rubescenti; elytris sulcatis, rubris, posteriùs denticulatis, pedibus nigro-cærulescentibus, tibis arcuatis. Long. 15 mill.; larg. 6 mill.) was found in the OUMNH (Fig. 8B), one of the main museums where Gory's specimens can be found (Maldaner et al., 2017).

A label handwritten "Para" is attached to this OUMNH specimen. Since no additional records have been made for this species in northern of Brazil, it is likely that the aforementioned record is the result of mislabelling. Gory (1831) mentioned "Du Brésil intérieur" [inland of Brazil] instead of "Para" as the type locality for D. rubripenne. However, we believe that "Para" could be interpreted as "Du Brésil intérieur", a simplified interpretation of the label content by Gory, since readers would not be familiriazed with the name 'Pará' in 1831.

The lectotype here designated has dark red elytra (Fig. 8B), different from other specimen photographed here (orange elytra) (Fig. 5A), as well from Gory's description ("roux jaunâtre également mat" [yellowish red evenly matte]). These variations were also found by us between syntopic specimens here analyzed. It was found just one type specimen of Hyboma rubripenne in the collections studied. Analyzing the original description (Gory 1831), we could not find any explicit mention that $H$. rubripenne was described based on a single specimen. However, due to those different elytral colorations mentioned above, we believe the type series was based on two or more individuals. Therefore, we designate here a lectotype rather than assume that the specimen we found is the holotype. This is in accordance with the International Commission on Zoological Nomenclature (1999) Recommendation 73F.

According to previously mentioned arguments, we recognize this specimen as a syntype and we designate it as the lectotype of $D$. rubripenne in accordance with Article 74 (specifically 74.1.1 and 74.7) of the ICZN (1999), with the purpose of maintaining nomenclatural stability.

Non-type material. ARGENTINA, MISIONES, Caianguás, Dos de Mayo, [27.036284 ${ }^{\circ} \mathrm{S}-54.675559^{\circ} \mathrm{W}$ ], XI.2007, E. Abadie leg. -1 unsexed specimen (CEMT). BRAZIL, MINAS GERAIS, Barbacena, Campus IFMT,

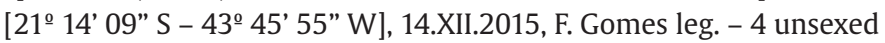

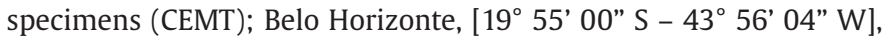
XII.1956, A. Machado leg. $-1+1{ }^{\jmath}$ (DZUP - ex M. Alvarenga collection); same data but, I.1957, A. Machado leg. - 1 ( (DZUP - ex M. Alvarenga

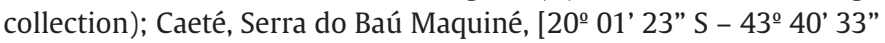
W], 1,623m, 02.VI-06.VII.2008, E. Bordoni leg. - 1 unsexed specimen (CEMT); same data but, [200 01’ 45" S - 43ํ 41' 01” W], 1,457m, 05.VI.2008, E. Bordoni leg. - 1 unsexed specimen (CEMT); Carrancas, [21 ${ }^{\circ} 29^{\prime} 23^{\prime \prime}$

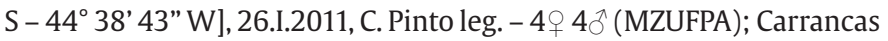
[atlantic forest], [ $21^{\circ} 24^{\prime} \mathrm{S}-44^{\circ} 35^{\prime} \mathrm{W}$ ], $1052 \mathrm{~m}$, pitfall with human dung, 31.I.2010, R. Macedo leg. - $2 \overbrace{}^{\AA}$ (MZUFPA); Carrancas [atlantic forest], [21 ${ }^{\circ} 25^{\prime} \mathrm{S}-44^{\circ} 35^{\prime} \mathrm{W}$ ], $1052 \mathrm{~m}$, pitfall with cow dung, 02.II.2010, R. Macedo leg. $-1+2 \overbrace{}^{\wedge}$ (MZUFPA); Catas Altas, Reserva Particular do Patrimônio Natural Santuário do Caraça [natural grassland], [20 06' 42" S - 43²8' 38” W], 21-23.X.2014, flight interception trap, M. Cupello, J. Botero, A. Carelli and M. L. Monné leg. - $1 \jmath^{\widehat{N}}$ (MNRJ); Catas Altas, Reserva Particular do Patrimônio Natural Santuário do Caraça, Trilha

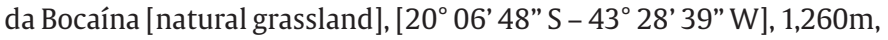
09-11.XII.2014, pitfall with human dung, M. Cupello and A. Carelli leg. - 1 q (MNRJ); Catas Altas, Reserva Particular do Patrimônio Natural
Santuário do Caraça, Trilha da Bocaína [natural grassland], [2006’ 50" S $43^{\circ} 28^{\prime} 38^{\prime \prime}$ W], 1,260m, 10-12.XII.2014, pitfall with rotten fish, M. Cupello leg. -8 ㅇ $5 \overbrace{}^{\lambda}$ (MNRJ); Catas Altas, Reserva Particular do Patrimônio Natural Santuário do Caraça, Trilha do Guigó [forest by a river], [2005’ 47" S - 432 29' 26” W], 1,260m, 10-12.XII.2014, pitfall with human dung, M.

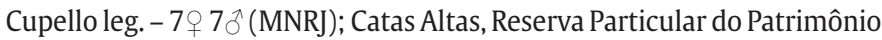
Natural Santuário do Caraça, Trilha do Guigó [forest by a river], [20 $\left.05^{\prime} 46^{\prime \prime} \mathrm{S}-43^{\circ} 29^{\prime} 27^{\prime \prime} \mathrm{W}\right], 1,260 \mathrm{~m}, 10-12 . X I I .2014$, pitfall with rotten fish, M. Cupello leg. - 18 8 (MNRJ); Conceição dos Ouros, [22,435106 ${ }^{\circ}$ S - 45,771056 W], 10.I.2001, E. Pereira leg. - 1 unsexed specimen (CEMT); Conceição dos Ouros, Rio Sapucaí, $\left[22,435106^{\circ} \mathrm{S}-45,771056^{\circ}\right.$ W], 01.I.2003, G. Almeida leg. - 2 unsexed specimens (CEMT); Lavras,

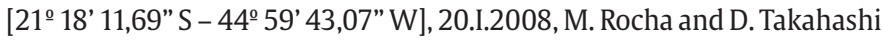

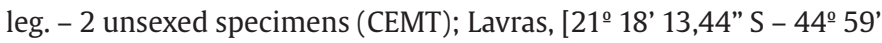
42,98" W], 20.I.2008, M. Rocha and D. Takahashi leg. - 1 unsexed

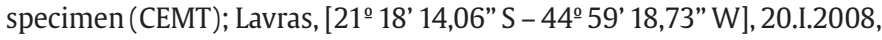
M. Rocha and D. Takahashi leg. -3 unsexed specimens (CEMT); Lavras,

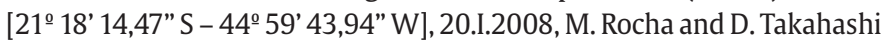

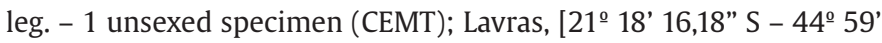
22,62" W], 20.I.2008, M. Rocha and D. Takahashi leg. - 2 unsexed

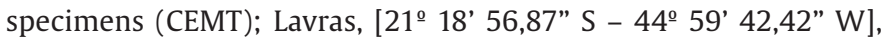
20.I.2008, M. Rocha and D. Takahashi leg. -1 unsexed specimen (CEMT);

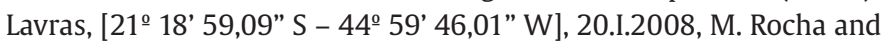
D. Takahashi leg. - 1 unsexed specimen (CEMT); Lavras, [21ํ19' 02,51"

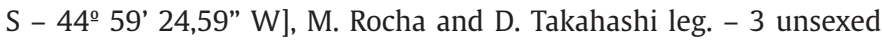

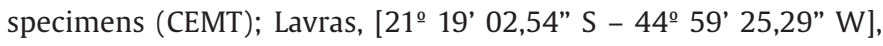
20.I.2008, M. Rocha and D. Takahashi leg. -1 unsexed specimen (CEMT);

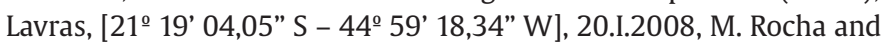
D. Takahashi leg. - 1 unsexed specimen (CEMT); Lavras, [21ํㅜㅇ' 10,81" S - 44ํㅜㅇ' 30,57” W], 20.I.2008, M. Rocha and D. Takahashi leg. - 1 unsexed specimen (CEMT); Lavras, [21ำ19' 11,78" S - 44ํ59' 31,23" W], 20.I.2008, M. Rocha and D. Takahashi leg. - 1 unsexed specimen

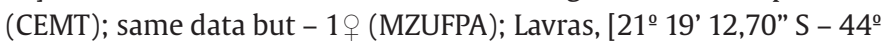
59' 32,23" W], 20.I.2008, M. Rocha and D. Takahashi leg. - 1 unsexed specimen (CEMT); Lavras, [21ํ19' 13,94” S - 44ํ59' 32,95” W], 20.I.2008, M. Rocha and D. Takahashi leg. - 1 unsexed specimen (CEMT); Lavras, Mata do Capivari, [21ำ16' 25” S - 44ํ16' 57” W], XII.2001, G. Schiffler leg. -2 ㅇ (MZUFPA); same data but - 21 unsexed specimens (CEMT); Lavras, near Poço Bonito, [21,328349 S - 44,968925 W], X.2001, P. Grossi and F. Vaz-de-Mello - 1 unsexed specimen (CEMT); Lavras, Serrinha, [21,271254 ${ }^{\circ}$ S - 45,010478 ${ }^{\circ}$ W], 03.III.2007, Rocha, Sâmia and Takahashi leg. - 1 unsexed specimen (CEMT); Passa Quatro, near Floresta Nacional de Passa Quatro, [22,385935 $\left.{ }^{\circ} \mathrm{S}-44,948002^{\circ} \mathrm{W}\right]$, F. FrieiroCosta leg. - 1 unsexed specimen (CEMT); Prados, Área de Proteção Ambiental São José [seasonal semideciduous atlantic forest], [21ํ04' 13" S - 44º 07' 04" W], 1,156m, 14.III.2012, pitfall with human dung, L. Vieira leg. - 1 unsexed specimen (CEMT); same data but, [210. 04' 35" S

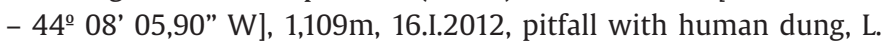

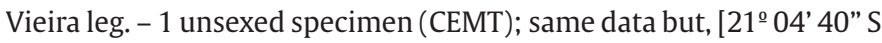

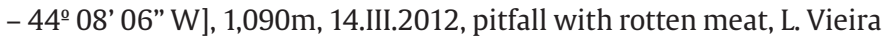
leg. - 2 unsexed specimens (CEMT); Rio Acima, [19ํ5' 33" S - 43 42' 35" W], 927m, 28.XI.2007, E. Bordoni leg. - 5 unsexed specimens (CEMT);

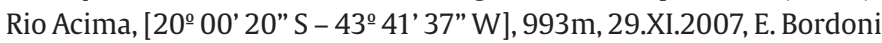
leg. - 7 unsexed specimens (CEMT); Rio Acima, [2001' 46" S - 43 41' 01" W], 1,457m, 30.XI.2007, E. Bordoni leg. - 1 unsexed specimen (CEMT); Rio

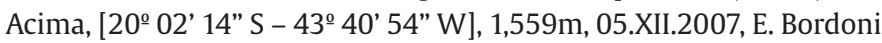
leg. - 3 unsexed specimens (CEMT); Rio Acima, Vale Mineração,

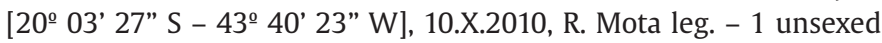

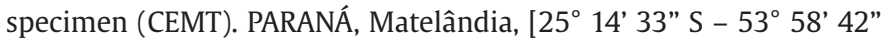

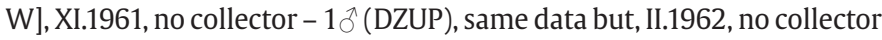

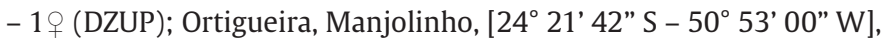
XI.1942, no collector - 1 ( (DZUP - F. Justus Jor collection); Pato Branco, 


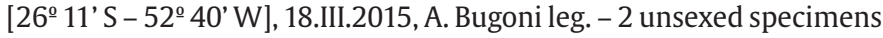

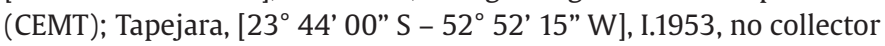

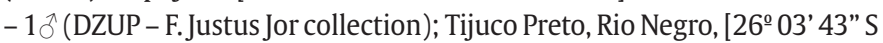
- 39은 53” W], V.2012, R. Marcolino leg. - 1 unsexed specimen (CEMT). RIO DE JANEIRO, Itatiaia, [22 $\left.25^{\prime} 56^{\prime \prime} \mathrm{S}-44^{\circ} 36^{\prime} 12^{\prime \prime} \mathrm{W}\right], 1,250 \mathrm{~m}$, 18.X.1931, J.Zikán leg. - 2 unsexed specimens (CEIOC); Itatiaia, [22,442824 ${ }^{\circ}$ S - 44,587844 $\left.{ }^{\circ} \mathrm{W}\right], 17 . X I .1991$, C. Júnior leg. - 2 unsexed specimens (CEMT); Itatiaia, Parque Nacional de Itatiaia, [ $22^{\circ} 20^{\prime} 30^{\prime \prime} \mathrm{S}-44^{\circ} 34^{\prime} 59^{\prime \prime} \mathrm{W}$ ], 1,200m, 30.X.2008, M. L. Monné, H. Freire and M. A. Monné leg.

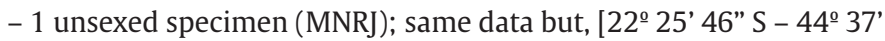
03" W], 1,100m, 23-26.XII.2011, C. Araújo and R. Andrade leg. - 1 unsexed

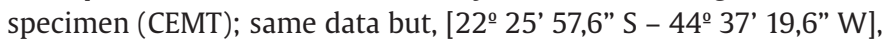
1,150m, 23-26.XII.2011, C. Araújo and R. Andrade leg. - 5 unsexed

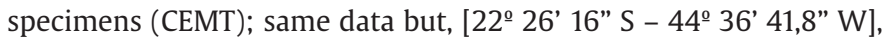
1,000m, 23-26.XII.2011, C. Araújo and R. Andrade leg. - 9 unsexed specimens (CEMT); same data but, [22을 $27^{\prime} 11^{\prime \prime} \mathrm{S}-44^{\circ} 36^{\prime} 28,4^{\prime \prime} \mathrm{W}$ ], 850m, 23-26.XII.2011, C. Araújo and R. Andrade leg. - 1 unsexed specimen

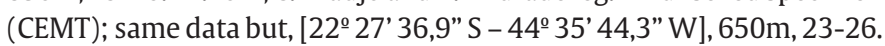
XII.2011, C. Araújo and R. Andrade leg. - 1 unsexed specimen (CEMT); Itatiaia, Parque Nacional de Itatiaia [Atlantic Forest], [22 $25^{\prime} 44^{\prime \prime} \mathrm{S}-44^{\circ}$ 37' 42" W], 1,450m, pitfall with human dung, 20.I.2012, C. Araújo leg. - $1 \delta^{\prime}$ (MZUFPA); same datat but, [22 $25^{\prime} 46^{\prime \prime} \mathrm{S}-44^{\circ} 37^{\prime} 38^{\prime \prime} \mathrm{W}$ ], $1350 \mathrm{~m}$, pitfall with human dung, 20.I.2012, C. Araújo leg. - $1 \delta^{\lambda}$ (MZUFPA); same datat but, [ $22^{\circ} 25^{\prime} 58^{\prime \prime} \mathrm{S}-44^{\circ} 37^{\prime} 20^{\prime \prime} \mathrm{W}$ ], $1150 \mathrm{~m}$, pitfall with human dung, 20.I.2012, C. Araújo leg. - 1 ( (MZUFPA); Itatiaia, Parque Nacional de Itatiaia [ombrophilous forest], [22 $27^{\circ} 17^{\prime \prime} \mathrm{S}-44^{\circ} 36^{\prime} 27^{\prime \prime} \mathrm{W}$ ], 810m, 17-18.XI.2012, V. Machado, J. Botero, A. Carelli and R. Souza leg. - 1 unsexed specimen (MNRJ); Itatiaia, Parque Nacional de Itatiaia, near Casa do Pesquisador [ombrophilous forest], [22 $27^{\circ} 15^{\prime \prime} \mathrm{S}-44^{\circ}$ 36' 26" W], 810m, 22-24.X.2010, pitfall with human dung, W. Beiroz and M. Cupello leg. - 1 unsexed specimen (MNRJ); same data but, 11-13.XI.2011, pitfall with human dung, M. Cupello leg. - 3 unsexed specimens (MNRJ); same data but, 27.II-01.III.2012, pitfall with human dung, M. Cupello leg. - 1 unsexed specimen (MNRJ); same data but, 22-25.II.2013, pitfall with rotten fish, M. Cupello leg. - 3 unsexed

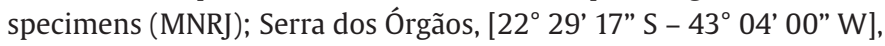
XII.1940, Parko leg. - 1 unsexed specimen (MNRJ). RIO GRANDE DO SUL, Erechim, Horto Florestal $\left[27,634787^{\circ} \mathrm{S}-52,274064^{\circ} \mathrm{W}\right], 31 . \mathrm{III} .2012$, R. Moraes and C. Badzinski - 1 unsexed specimen (CEMT); Mato Castelhano, Floresta Nacional de Passo Fundo, [28,297077 ${ }^{\circ} \mathrm{S}-$ 52,212471 ${ }^{\circ} \mathrm{W}$ ], 01.II.2009, R. Moraes leg. - 1 unsexed specimen (CEMT);

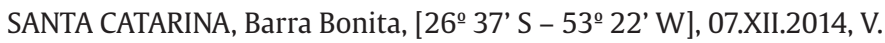
Alves leg. - 1 unsexed specimen (CEMT); Florianópolis, Lagoa do Peri,

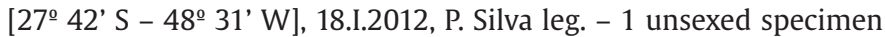

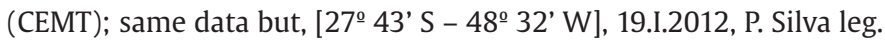
- 2 unsexed specimens (CEMT); same data but, [27은 $42^{\prime} \mathrm{S}-48^{\circ} 31^{\prime} \mathrm{W}$ ], 01.II.2013, P. Silva leg. - 2 unsexed specimens (CEMT); Florianópolis,

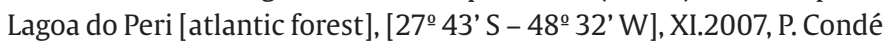
and M. Hernández leg. - 2 unsexed specimens (CEMT); same data but, [27 43' S - 48o 32' W], I.2009, A. Martin and M. Hernández leg. - 1 unsexed specimen (CEMT); Florianópolis, Unidade de Conservação

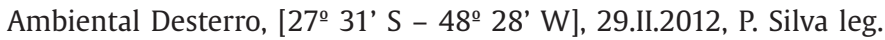
- 2 unsexed specimens (CEMT); same data but, [27은 $31^{\prime} \mathrm{S}-48^{\circ} 30^{\prime} \mathrm{W}$ ], 09.I.2013, P. Silva leg. - 1 unsexed specimen (CEMT); same data but,

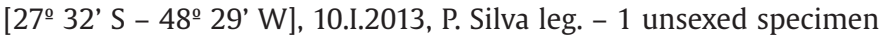

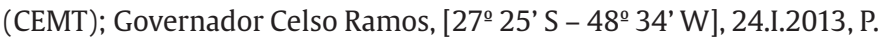
Silva leg. - 2 unsexed specimens (CEMT); Ipumirim, [27을 $02^{\prime} \mathrm{S}-52^{\circ}$ 10' W], 25.XII.2012, J. Bogoni leg. - 1 unsexed specimen (CEMT);

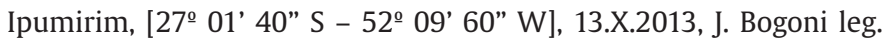

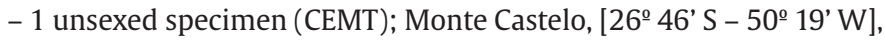
07.I.2013, A. Brandi leg. - 1 unsexed specimen (CEMT); Santo Amaro

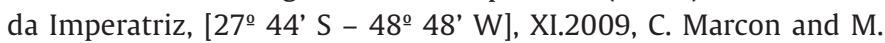

Hernández leg. - 3 unsexed specimens (CEMT). SÃO PAULO, Campinas, [22,909938 $\left.{ }^{\circ} \mathrm{S}-47,062633^{\circ} \mathrm{W}\right], 26.1 .1997$, Lopes and Mello leg. -2 unsexed specimens (CEMT); São Miguel Arcanjo, Parque Estadual Carlos Botelho,

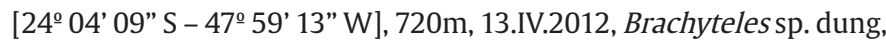
M. Boutefeu leg. - 1 unsexed specimen (CEMT); São Paulo, Cerqueira César, [23,559214 ${ }^{\circ} \mathrm{S}-46,667732^{\circ} \mathrm{W}$ ], XI.1998, J. Carlos leg. -5 unsexed specimens (CEMT); Parque Estadual da Serra do Mar, Núcleo Santa Virgínia, Sede Vargem Grande, [23ํ26’ 30” S - 45ํ14' 19” W], 17.I.2012, M. Boutefeu leg. - 2 unsexed specimens (CEMT); same data but - $1 \delta^{\lambda}$ (MZUFPA); Parque Estadual da Serra do Mar, Núcleo Santa Virgínia,

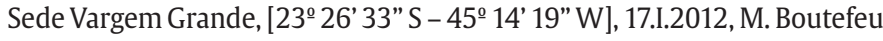
leg. - 10 unsexed specimens (CEMT); same data but - 1 ㅇ (MZUFPA); Parque Estadual da Serra do Mar, Núcleo Santa Virgínia, Sede Vargem Grande, [232 26' 15" S - 451' 17” W], 17.I.2012, E. Bovy leg. - 1 unsexed

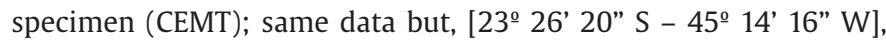
17.I.2012, E. Bovy leg. -2 unsexed specimens (CEMT); same data but,

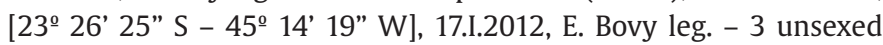

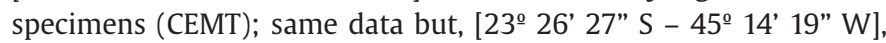
17.I.2012, E. Bovy leg. - 4 unsexed specimens (CEMT); same data but,

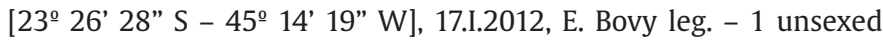

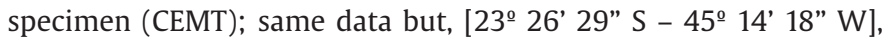
17.I.2012, M. Boutefeu leg. - 2 unsexed specimens (CEMT); same data but, [232 26' 29" S - 45ํ14' 19" W], 17.I.2012, M. Boutefeu leg. - 7 unsexed

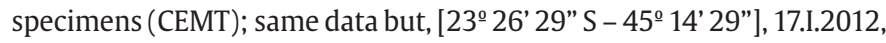
E. Bovy leg. - 1 unsexed specimen (CEMT); same data but, [232 26' 34" S - 45ํ1' 20" W], 17.I.2012, M. Boutefeu leg. - 1 unsexed specimen (CEMT); same data but, [2326' 35” S - 45 14' 21” W], 17.I.2012, M. Boutefeu leg. - 2 unsexed specimens (CEMT); same data but, [23ํㅡㄹ 38" S - 4514' 23" W], 17.I.2012, M. Boutefeu leg. - 2 unsexed specimens (CEMT); same data but, [23 26' 39" S - 45 14' 23” W], 17.I.2012, M. Boutefeu leg. - 12 unsexed specimens (CEMT); same data but, [23⒉ 40" S - 45ํㅜㄴ' 25" W], 17.I.2012, M. Boutefeu leg. - 4 unsexed specimens (CEMT); Serra do Japi, [23,236338 $\left.{ }^{\circ} \mathrm{S}-46,943506^{\circ} \mathrm{W}\right]$, XII.1998, M. Medina leg. -5 unsexed specimens (CEMT); Serra do Japi [forest], [23ำ 14' S - 46ํ5' W], 1,050m, 1998, M. Hernández leg. - 6 unsexed specimens (CEMT); same data but - 19 (MZUFPA). PARAGUAY, ITAPÚA,

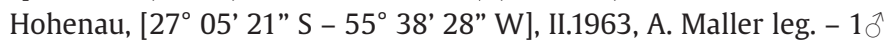
(DZUP).

Diagnosis. It differs from all species of Deltochilum by the following combination of characters: ninth elytral interstria lacking carina at base, or carina inconspicuous (Fig. 1F). Elytral interstriae 1-7 with a longitudinal row of tubercles. Elytral base carinate only at seventh interstria. Elytra carinate at apex of second, third, fourth, fifth, sixth and seventh interstriae. Protarsi absent.

Body. Head and pronotum light brown. Elytra orange to dark red. Ventral surface black, with bluish sheen. Body surface with dense granulation, visible at high magnification. Length. 11 to $13 \mathrm{~mm}$. Head. Foveiform punctures and microtubercles spaced by approximately once or twice their diameter. Clypeal edge with two medial teeth, edge expanded in angle of approximately 90 degrees between clypeal teeth and clypeogenal suture. Clypeal teeth with setae at base. Thorax. Surface of pronotum with dense microtubercles and foveiform punctures; denser and confluent at lateral portions, and spaced by once their diameter at pronotal disc. Pronotum with small depression close to lateral angles. Anterior angles acute, directed forward. Hypomera not excavated, with dense foveiform punctures on anterior portion; punctures on posterior portion denser at internal and external edges. Metaventrite with excavation near to posterior edge. Metaventrite punctures variable in size; smaller along anterior region and larger at lateral edges, metanepisternum and mesepimeron. Elytra. Punctures of elytral striae spaced by once or twice their diameter. Elytral interstriae with foveiform punctures; denser on the first interstria and more spaced in others. Ninth elytral 
interstria lacking carina at base, or carina inconspicuous (Fig. 1F). Elytral interstriae 1-7 with a longitudinal row of tubercles. Elytral base carinate only at seventh interstria. Elytra carinate at apex of second, third, fourth, fifth, sixth and seventh interstriae. Abdomen. Punctures large and conspicuous at lateral portions of ventrites, reduced to a narrow belt along midline of ventrites. Pygidium rounded at apex, densely punctate. Legs. Medial lateral tooth of protibia closer to apical tooth than to basal tooth. Protibial teeth with setae at base. Dorsal surface of protibia with a longitudinal row of tubercles. Surface of profemur with rounded and elliptical foveiform punctures. Meso- and metafemur with small and sparse punctures. Longitudinal carina of the meso and metatibia with row of setae. Meso- and metatarsomeres 1-4 trapezoid, the last subrectangular. Sexual dimorphism. Females can be distinguished from males, in general, by the protibial spur acuminate at apex (Fig. 5E) [in males, spur rounded at apex (Fig. 5F)]; posterior edge of metatrochanter regular, lacking expansion (in males, posterior edge of metatrochanter expanded towards the abdominal ventrites, spiniform-shaped); posterior edge of metafemur substraight (Fig. 5C) [in males, posterior edge of metafemur expanded and curved towards abdominal ventrites along its proximal third (Fig. 5D)]; metatibia with tubercles along its internal edge more conspicuous in males; meso- and metatibia more curved in males. Tegmen. Parameres symmetrical, subrectangular in lateral view, with setae at apex (Fig. 6D). Endophallus. Lamella Copulatrix (LC) (Fig. 7D). Left lobe subrectangular (Fig. 7D); right lobe subtriangular, nearly 1.5 times longer than the left lobe (Fig. 7D). Superior Right Peripheral (SRP) endophallite with circular ring and truncated cable (Fig. 7D). Frontolateral Peripheral (FLP) endophallite, and Complex of Axial and Subaxial (A+SA) endophallites elongate, irregular (Fig. 7D).

Biogeographical regions. Parana dominion (Atlantic, Parana, and Araucaria forest provinces) (see Morrone 2014: fig. 12).

Distribution. Known from Brazil: (Minas Gerais, Rio de Janeiro, São Paulo, Paraná, Santa Catarina, and Rio Grande do Sul); Paraguay (Itapúa); and Argentina (Misiones) (Fig. 11). Additionally, the species was also recorded in Brazil from Cantagalo and Teresópolis [Serra dos Órgãos] (Rio de Janeiro), Jundiaí and Vinhedo (São Paulo) and Piraquara (Paraná) by Harold (1875), Paulian (1939), Pessôa and Lane (1941), and Lange (1947).

\section{Discussion}

The symmetry of the parameres has been an important character studied in Deltochilini (Medina et. al., 2003; González-Alvarado et al., 2009; Génier, 2012; Silva et al. 2015; Cupello and Vaz-de-Mello, 2018; Silva and Valois, 2019). Most of Deltochilini have symmetric parameres (Medina et al., 2003), as also verified in specimens examined herein. However, some species of Canthon [e.g., C. aberrans (Harold, 1868)], Scybalocanthon [S. federicoescobariSilva and Valois 2019, S. martinezi Silva and Valois 2019, S. papaxibe Silva and Valois 2019, S. pygidialis (Schmidt, 1922), S. uniplagiatus (Schmidt, 1922)] and Deltochilum s. str. have strongly asymmetrical parameres (Medina et al., 2003; González-Alvarado et al., 2009; Génier, 2012; Silva and Valois, 2019).

Regarding the shape of the parameres, those of D. (Euhyboma) brasiliense is tapered towards the apex in lateral view (Fig. 6A). Those of D. (Parahyboma) furcatum, D. (Parahyboma) granulosum and $D$. (Rubrohyboma) rubripenne, in turn, are subrectangular in lateral view (Figs 6B-6D). The apex of the parameres in both species of Parahyboma, in particular, has a downward projection in their ventral edge (Figs 6B-6C). On the other hand, the parameres of $D$. rubripenne are unique in having a tuft of setae at the apex of their dorsal edge (Fig. 6D). The proportion between the length of the parameres and the phallobase also shows some differences between the species. In $D$. brasiliense, the parameres have more than half the length of the phallobase (Fig. 6A). Deltochilum rubripenne has parameres with approximately $2 / 3$ of the length of phallobase (Fig. 6D), while in both species of $D$. (Parahyboma) the parameres have approximately $1 / 3$ of the length of phallobase (Figs 6B-6C).

We found some differences in the geographical distribution patterns for each of the species studied. These differences are related to biogeographic dominions, latitudinal variation, phytophysiognomies, and the areas wherein each species was recorded. Deltochilum brasiliense inhabits the biogeographic dominions of Parana (Atlantic, Parana forest, and Araucaria forest provinces) and Chaco (Pampean province), mainly in Atlantic rainforest ecosystems, such as Altitudinal Atlantic forest, Submontane and Montane forests, Dense Ombrophilous forest, Gallery forest, and Araucaria forest (Almeida and Louzada, 2009; Silva et al., 2011; Silva and Di Mare, 2012; Bogoni and Hernández, 2014; Silva et al., 2014; Silva et al., 2018). Apart from records in forested areas, it also has one record in natural grassland along the Pampean region (Rio Grande do Sul: Rolante), and a single record in Savanna (Minas Gerais: Prados, "Área de Proteção Ambiental Serra de São José"). However, there are many gallery forests close to both localities. It is possible, therefore, that the species accesses these open areas through gallery forests. Among the analyzed species, Deltochilum brasiliense was the only with records from Altitudinal Atlantic forest (eastern portion of Pernambuco), and it also has the broadest latitudinal range of occurrence $\left(8^{\circ}-30^{\circ} \mathrm{S}\right)$ in comparison to the other species studied here ( D. furcatum: $19^{\circ}-27^{\circ} \mathrm{S}$; D. granulosum: $13^{\circ}-19^{\circ} \mathrm{S}$; D. rubripenne: $21^{\circ}-27^{\circ} \mathrm{S}$ ).

Deltochilum furcatum and $D$. rubripenne have been reported from Submontane and Montane forests, Dense Ombrophilous forest and Araucaria forest, inhabiting primary and secondary forests (Almeida and Louzada, 2009; Hernández and Vaz-de-Mello, 2009; Lopes et al., 2011; Silva et al., 2011; Silva and Di Mare, 2012; Culot et al., 2013; Bogoni and Hernández, 2014; Gómez et al., 2018). Deltochilum granulosum has been recorded from Submontane and lowland forests, being recorded in primary and secondary Atlantic rainforest (Audino et al., 2014), only inhabiting lowlands near the coast.

According to the label data from specimens examined here, $D$. brasiliense, $D$. furcatum, and $D$. rubripenne have several records along mountain ranges in southern Brazil (from the Serra de São José in the central portion of Minas Gerais to the Serra Geral in the northeastern Rio Grande do Sul). In addition to records from mountain ranges, these species also occur in plain areas with elevation close to sea level. However, these records were not frequent in comparison to records in plateau areas. In contrast, records for D. granulosum were frequent in areas with elevation close to sea level in comparison to plateau areas.

Until now, there have been no cases of sympatry between the two species of the subgenus Parahyboma. Although the species occur in nearby regions in the central portion of Espírito Santo, their ranges are separated by the course of the Doce River, $D$. granulosum occurring to the north of this river, whereas $D$. furcatum is limited to the south of it (Fig. 10).

\section{Acknowledgements}

We thank Fernando Z. Vaz-de-Mello (CEMT) for sending specimens to us and for sharing his photographs of the type specimens deposited in Europe. We also thank Mario Cupello for providing data of CEIOC, DZUP, and MNRJ collections, as well for his valuable comments on early versions of manuscript, whose comments and suggestions have improved the quality of our manuscript. We also thank Coordenação de Aperfeiçoamento de Pêssoal de Nível Superior Pro-equipamentos/Universidade Federal do Pará for providing the photographic equipment used, and the Conselho Nacional de Desenvolvimento Científico e Tecnológico (CNPq) for providing research grants for FABS (444020/2014-4) and PIBIC 
fellowships for EENS. FABS is a Conselho Nacional de Desenvolvimento Científico e Tecnológico fellow.

\section{Conflicts of interest}

The authors declare no conflicts of interest.

\section{Author contribution statement}

All authors contributed to taxonomic revision and decisions in this work. EENS: Conceptualization, Data curation, Methodology, Formal analysis, Writing- Original draft preparation. FABS: Conceptualization, Methodology, Project administration, Validation, Resources, Supervision, Writing- Reviewing and Editing.

\section{References}

Almeida, S. S. P., Louzada, J. N. C., 2009. Estrutura da comunidade de Scarabaeinae (Scarabaeidae: Coleoptera) em fitofisionomias do Cerrado e sua importância para a conservação. Neotrop. Entomol. 38, 32-43. https://doi.org/10.1590/S1519-566X2009000100003.

Audino, L. D., Louzada, J., Comita, L., 2014. Dung beetles as indicators of tropical forest restoration success: is it possible to recover species and functional diversity? Biol. Conserv. 169, 248-257. https://doi. org/10.1016/j.biocon.2013.11.023.

Blackwelder, R. E., 1944. Checklist of the coleopterous insects of Mexico, Central America, West Indies and South America. Part 2. Bull. U. S. Natl. Mus. 185, 189-341.

Bogoni, J. A., Hernández, M. I. M., 2014. Attractiveness of native mammal's feces of different trophic guilds to dung beetles (Coleoptera: scarabaeinae). J. Insect Sci. 14, 1-7. https://doi.org/10.1093/jisesa/ ieu161.

Bruch, C., 1911. Catálogo sistemático de los coleópteros de la República da Argentina. Revista del Museo dela Plata. 17, 104-109.

Burmeister, H., 1848. Die Entwiekelungsgeschichte der Gattung Deltochilum Esch. Zeitung für Zoologie. Zootomie Palaeozoologie. 1 (17), 133-136.

Cambefort, Y., 2006. Des Coléoptères, des Collections and des Hommes. Publications Scientifiques du Muséum national d'Historie naturelle, Paris, 375 pp.

Castelnau, C., 1840. Histoire Naturelle des Insectes Coléoptères. Tome deuxième. Histoire Naturelle des animaux articulées, crustacés, arachnides, myriapode et insectes. Tome troisième, P. Duméril, Paris, 546 pp.

Culot, L., Bovy, E., Vaz-de-Mello, F. Z., Guevara, R., Galetti, M., 2013. Selective defaunatiomn affects dung beetle communities in continuous Atlantic rainforest. Biol. Conserv. 163, 79-89. https:// doi.org/10.1016/j.biocon.2013.04.004.

Cupello, M., Vaz-de-Mello, F. Z., 2018. A monographic revision of the Neotropical dung beetle genus Sylvicanthon Halffter \& Martínez, 1977 (Coleoptera: Scarabaeidae: Scarabaeinae: Deltochilini), including a reappraisal of the taxonomic history of 'Canthon sensu lato'. Eur. J. Taxon. 467, 1-205. https://doi.org/10.5852/ejt.2018.467.

Eschscholtz, F., 1822. Entomographien. Erste Lieferung. Mit zwei illuminirten Kupfertafeln. G. Reimer, Berlin, 128 pp.

Génier, F., 2012. A new species and notes on the subgenus Deltochilum (Deltochilum) Eschscholtz, 1822 (Coleoptera: Scarabaeidae: Scarabaeinae: Deltochilini). Zootaxa 3357, 25-36. https://doi. org/10.11646/zootaxa.3357.1.2.

Génier, F., 2019. Endophallites: a neologism for naming the sclerotized elements of the insect endophallus (Arthropoda: Insecta). Ann.
Soc. Entomol. Fr. 55, 482-484. https://doi.org/10.1080/00379271 2019.1685907.

Gillet, J., 1911. Coleopterorum Catalogus. Pars 38: Scarabaeidae: Coprinae I. W. Junk, Berlin, 100 pp.

Gómez, G. V. C., Verdú, J. R., Guerra-Alonso, C. B., Zurita, G. A., 2018. Relationship between land uses and diversity of dung beetles (Coleoptera: Scarabaeinae) in southern Atlantic forest of Argentina: which are the key factors? Biodivers. Conserv. 27, 3201-3213. https:// doi.org/10.1007/s10531-018-1597-8.

González-Alvarado, F. A., Molano, F. R., Medina, C. A. U., 2009. Los subgéneros Calhyboma, Hybomidium y Telhyboma (Coleoptera: Scarabaeidae: Scarabaeinae: Deltochilum) en Colombia. Rev. Colomb. Entomol. 35, 253-274.

Gory, H. L., 1831. [Description of] Hyboma rubripennis. Magazin. Zool. 1, 37.

Halffter, G., Edmonds, W. D., 1982. The Nesting Behavior of Dung Beetles (Scarabaeidae): an Ecological and Evolutive Approach. Instituto de Ecologia, Mexico City, 176 pp.

Halffter, G., Matthews, E. G., 1966. The natural history of dung beetles of the subfamily Scarabaeinae (Coleoptera: scarabaeidae). Folia Entomol. Mex. 12, 1-312.

Harold, E., 1869. Catalogus Coleopterorum. Hucusque Descriptorum, Synonymicus et Systematicus. Tom. IV. Scarabaeidae. E. H. Gummi, Munich, pp. 979-1346.

Harold, E., 1875. Verzeichniss der von Dr. Teuscher in Cantagallo gesammelten coprophagen Lamellicornien. Coleopterologische Hefte. 13, 58-181.

Hernández, M. I. M., Vaz-de-Mello, F. Z., 2009. Seasonal and spatial species richness varation of dung beetle (Coleoptera, Scarabaeidae s. str.) in the Atlantic Forest of southeastern Brazil. Rev. Bras. Entomol. 53,607-613. https://doi.org/10.1590/S0085-56262009000400010. International Commission on Zoological Nomenclature - ICZN, 1999. International Code of Zoological Nomenclature. 4th ed. International Trust for Zoological Nomenclature, London, $306 \mathrm{pp}$. Adopted by the International Union of Biological Sciences.

Kolbe, H. J., 1893. Beiträge zur kenntniss der mistkafer, Lamellicornia onthophila. Stettiner entomologische Zeitung. 54, 188-202.

Krajcik, M., 2006. Checklist of Scarabaeoidea of the World. 1. Scarabaeinae (Coleoptera: Scarabaeidae: Scarabaeinae). Selbstverl, Czech Rep., 189 pp. (Animma. X., 3).

Krajcik, M., 2012. Checklist of the World Scarabaeoidea. Selbstverl, Czech Rep. 278 pp. (Animma. X., 5).

Lane, F., 1946. Sôbre os tipos e a sinonímia de alguns Canthonini (Col. Scarabaeidae). Parte II. Papeis Avulsos Dep. Zoologia. 8, 109-121.

Lange, R. B., 1947. Ensaio da zoogeografia dos Scarabaeidae do Paraná com algumas notas eto-ecológicas. Arquivo Mus. Parana. 6, 305-315.

Lopes, J., Korasaki, V., Catelli, L. L., Marçal, V. V. M., Nunes, M. P. B. P., 2011. A comparison of dung beetle assemblage structure (Coleoptera: Scarabaeidae: Scarabaeinae) between an Atlantic forest fragment and adjacent abandoned pasture in Paraná, Brazil. Zoologia 28, 7279. https://doi.org/10.1590/S1984-46702011000100011.

Maldaner, M. E., Cupello, M., Ferreira, D. C., Vaz-de-Mello, F. Z., 2017. Type specimens and names assigned to Coprophanaeus (Megaphanaeus) d'Olsoufieff, 1924, the largest New World dung beetles (Coleoptera: Scarabaeidae: Phanaeini). Zootaxa 4272, 83-102. https://doi. org/10.11646/zootaxa.4272.1.4.

Martínez, A., 1959. Catálogo de los Scarabaeidae Argentinos. Revista del Museo Argentino de Ciencias Naturales. Bernardino Rivadavia $5,1-126$.

Medina, C. A., Lopera-Toro, A., Vítolo, A., Gill, B., 2001. Escarabajos Coprófagos (Coleoptera: Scarabaeidae: Scarabaeinae) de Colombia. Biota Colomb. 2, 131-144. 
Medina, C. A., Scholtz, C. H., Gill, B. D., 2003. Morphological variation and systematics of Canthon Hoffmansegg, 1817 and related genera of New World Canthonini dung beetles (Coleoptera, Scarabaeinae). Dtsch. Entomol.Z. 50, 23-68. https://doi.org/10.1002/mmnd.20030500105.

Morrone, J. J., 2014. Biogeographical regionalisation of the Neotropical region. Zootaxa 3782, 1-110. https://doi.org/10.11646/zootaxa.3782.1.1.

Paulian, R., 1933. Coprophages américains nouveaux ou peu connus. Bull. Soc. Entomol. Fr. 38, 204-205.

Paulian, R., 1938. Contribution à l'étude des canthonides américains. Annales de la société entomologique de France. Pars. 1 (107), 213-296.

Paulian, R., 1939. Contribution à l'etude des Canthonides Americains. Annales de la societé entomologique de France. Pars. 2 (108), 1-40.

Pereira, F., Martínez, A., 1956. Os generos de Canthonini americanos. Rev. Bras. Entomol. 6, 91-192.

Pessôa, S. B., Lane, F., 1941. Coleópteros necrófagos de interesse médicolegal: ensaio monográfico sobre a família Scarabaeidae de S. Paulo e regiões vizinhas. Arq. Zoologia Estado Sao Paulo. 2, 389-504.

Redtenbacher, L., 1868. Reise der österreichischen Fregatte Novara um die Erde in den Jahren 1857, 1858, 1859 unter den Befehlen des Commodore B. von Wüllerstorf-Urbair. Zoologischer Theil. Zweiter Band. Coleopteren. Mit 5 Tafeln. Karl Gerold's Sohn, Vienna, iv + 249 pp. +5 pls.

Schoolmeesters, P. (2020) Scarabs: world scarabaeidae database (version 2020-07-01). In: Roskov, Y., Ower, G., Orrell, T., Nicolson, D., Bailly, N., Kirk, P. M., Bourgoin, T., DeWalt, R. E., \& Decock, W., Nieukerken, E. van, Penev, L. (Eds.), Species 2000 \& ITIS Catalogue of Life, 2020-0901 Beta. Species 2000, Naturalis, Leiden, the Netherlands. Available in: www.catalogueoflife.org/col (accessed 20 September 2020).

Shipp, J. W., 1897. On the synonymy of the genus Deltochilum. Entomol. Nachr. 23, 194-196.

Silva, F. A. B., Louzada, J., Vaz-de-Mello, F. Z., 2015. A revision of the Deltochilum subgenus Aganhyboma Kolbe, 1893 (Coleoptera: Scarabaeidae: Scarabaeinae). Zootaxa 3925, 451-504.

Silva, F. A. B., Valois, M. C., 2019. A taxonomic revision of the genus Scybalocanthon Martínez, 1948 (Coleoptera: Scarabaeidae: Scarabaeinae: Deltochilini). Zootaxa 4629, 301-341. https://doi. org/10.11646/zootaxa.4629.3.1.

Silva, P. G., Vaz-de-Mello, F. Z., Di Mare, R. A., 2011. Guia de identificação das espécies de Scarabaeinae (Coleoptera: Scarabaeidae) do município de Santa Maria, Rio Grande do Sul, Brasil. Biota Neotrop. 11, 329-345.

Silva, P. G., Di Mare, R. A., 2012. Escarabeíneos copro-necrófagos (Coleoptera, Scarabaeidae, Scarabaeinae) de fragmentos de Mata
Atlântica em Silveira Martins, Rio Grande do Sul, Brasil. Iheringia Ser. Zool. 102, 197-205.

Silva, P. G., Lobo, J. M., Hensen, M. C., Vaz-de-Mello, F. Z., Hernández, M. I. M., 2018. Turnover and nestedness in subtropical dung beetle assemblages along an elevational gradient. Divers. Distrib. 24, 1277-1290. https://doi.org/10.1111/ddi.12763.

Silva, V. C., Cipolatto, R. P., Abegg, A. D., Rosa, M. C., Silva, P. G., Di Mare, R. A., 2014. Escarabeídeos (Coleoptera: Scarabaeidae) de campo e floresta da Reserva Biológica de São Donato, Rio Grande do Sul, Brasil. Biotemas 27, 63-71. https://doi.org/10.5007/21757925.2014v27n4p63.

Tarasov, S. I., Solodovnikov, A. Y., 2011. Phylogenetic analyses reveal reliable morphological markers to classify mega-diversity in Onthophagini dung beetles (Coleoptera: Scarabaeidae: Scarabaeinae). Cladistics 27, 490-528. https://doi.org/10.1111/j.1096-0031.2011.00351.x.

Tarasov, S., Génier, F., 2015. Innovative Bayesian and Parsimony Phylogeny of Dung Beetles (Coleoptera, Scarabaeidae, Scarabaeinae) Enhanced by Ontology-Based Partitioning of Morphological Characters. PLoS One 10, 1-86. https://doi.org/10.1371/journal.pone.0116671.

Vaz-de-Mello, F. Z., 1999. Scarabaeidae s. str. (Coleoptera: Scarabaeoidea) de um fragmento de Floresta Amazônica no Estado do Acre, Brasil. 1. Taxocenose. An. Soc. Entomol. Bras. 28, 447-453.

Vaz-de-Mello, F. Z., 2000. Estado atual de conhecimento dos Scarabaeinae s. str. (Coleoptera: Scarabaeiodea) do Brasil. In: Martín-Piera, F., Morrone, J. J., Melic, A., (Eds.), Hacia un Proyecto CYTED para el Inventario Y Estimación de la Diversidad Entomológica en Iberoamérica: PrIBES-2000. Monografias Tercer Milenio \& Sociedad Entomológica Aragonesa, Zaragoza, pp. 183-195.

Vaz-de-Mello, F. Z., 2020. Scarabaeinae in Catálogo Taxonômico da Fauna do Brasil. PNUD. Available in: http://fauna.jbrj.gov.br/fauna/ faunadobrasil/127498 (accessed 20 September 2020).

Vaz-de-Mello, F. Z., Edmonds, W. D., Ocampo, F. C., Schoolmeesters, P., 2011. A multilingual key to the genera and subgenera of the subfamily Scarabaeinae of the New World (Coleoptera: scarabaeidae). Zootaxa 2854, 1-73.

Vulcano, M. A., Pereira, F. S., 1964. Catalogue of the Canthonini (Col. Scarab.) inhabiting the Western Hemisphere. Entomologische Arbeiten aus dem Museum G. Frey. 15, 570-685.

Vulcano, M. A., Mascarenhas, C. S., Pereira, F. S., 1980. Anthologia Zoologica Caracensis - I. Coleoptera. Lundiana. 1, 99-128.

Zunino, M., 1978. L'armatura genitale negli Onthophagini: tecniche di preparazione e criteri di studio. Boll. Soc. Entomol. Ital. 90, 21-26. 